\title{
Testing tritium-helium groundwater dating in the Chalk aquifer of the Berkshire Downs, UK
}

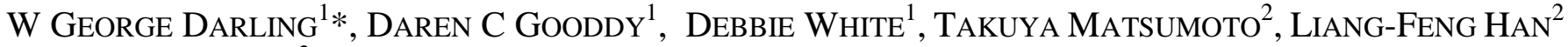 \\ and NICOLO ROMEO ${ }^{2}$ \\ 1. British Geological Survey, Maclean Building, Wallingford, OX10 8BB, UK \\ 2. Isotope Hydrology Section, International Atomic Energy Agency, Vienna International
}

The tritium-helium $\left({ }^{3} \mathrm{H} /{ }^{3} \mathrm{He}\right)$ dating method has been applied to the Chalk (fractured microporous limestone) aquifer in the UK for the first time. An evaluation of the results from diffusion cell versus pumped tube sampling showed generally good agreement between the two techniques. Measurements of noble gas ( $\mathrm{Ne}, \mathrm{Ar}, \mathrm{Kr}$ and $\mathrm{Xe}$ ) concentrations revealed typically low amounts of excess air in the aquifer, with little variation around a mean of 1.3 ccSTP/kg suggesting the predominance of steady recharge via the microporosity rather than via the fracture network. Chalk boreholes are generally unlined, with discrete inflows from a few fracture-related flow horizons. Despite this, attempts to detect age layering in the water column by suspension of diffusion samplers or by slowpumping were unsuccessful. However, when short-screen piezometers were used, better evidence for an age-depth relationship was obtained. Assuming a piston-flow model of water movement, a vertical flowrate of $\sim 3.3 \mathrm{~m} / \mathrm{yr}$ was indicated. However, a more complex picture of movement was obtained by comparing total ${ }^{3} \mathrm{H}$ activity (including the ${ }^{3} \mathrm{He}$ decay equivalent) against $\mathrm{SF}_{6}$ concentration, which suggested the existence of various modes of mixing. This would be consistent with the high degree of fracturing that exists in the Chalk.

Keywords: groundwater dating, excess air, noble gases, Chalk aquifer

\section{INTRODUCTION}

The dating of young ( $<60$ year old) groundwaters can be attempted by several techniques. The first to be used was tritium $\left({ }^{3} \mathrm{H}\right)$, which came to attention owing to the atmospheric testing of thermonuclear devices in the 1950s and early 1960s (Münnich et al., 1967). This was followed by use of the industrially-derived atmospheric trace gases CFCs (chlorofluorocarbons) and $\mathrm{SF}_{6}$ (sulphur hexafluoride) (e.g. Oster et al., 
1996; Busenberg and Plummer, 2000), and by ${ }^{85} \mathrm{Kr}$, which is produced during reactor fuel rod reprocessing (e.g. Visser et al., 2013).

All these methods are attended by limitations. Tritium is now present in the northern hemisphere atmosphere at activities close to background (IAEA-WMO GNIP database, https://nucleus.iaea.org/wiser). The CFCs may be enhanced by local contamination or degraded under reducing conditions, while $\mathrm{SF}_{6}$ may be enhanced from geogenic sources (e.g. Darling et al., 2012a). The use of ${ }^{85} \mathrm{Kr}$ is currently constrained by a combination of sample size, laboratory availability and cost (e.g. Newman et al., 2010). Each method also relies on a knowledge of the input history of the tracer in the area of investigation; this is a particular issue in the case of ${ }^{3} \mathrm{H}$, which is not well mixed in the atmosphere (e.g. Eriksson, 1965).

In the late 1960s it was proposed that the measurement of the ${ }^{3} \mathrm{He}$ resulting from ${ }^{3} \mathrm{H}$ decay could be used to improve on the standard tritium dating tool (Tolstikhin and Kamenskiy, 1969), because a knowledge of input history was not required. However it was not until nearly two decades later that the method was applied to hydrogeology (Schlosser, 1992). Following the establishment of the Noble Gases Laboratory, part of the Isotope Hydrology Section of the International Atomic Energy Agency (IAEA), the ${ }^{3} \mathrm{H} /{ }^{3} \mathrm{He}$ method (sometimes referred to as ' $\mathrm{T} /{ }^{3} \mathrm{He}$ ', or simply 'tritium-helium') is now a method available to a wide range of hydrogeologists. An IAEA Co-ordinated Research Project (CRP) on ${ }^{3} \mathrm{H} /{ }^{3} \mathrm{He}$ dating (CRP 1786: Tritium ${ }^{3}$ He dating and noble gas techniques in water resources management: recharge, infiltration conditions and groundwater balance) provided the British Geological Survey (BGS) with the first opportunity to try this form of groundwater dating in the UK. The aquifer chosen for investigation was a $750 \mathrm{~km}^{2}$ area of the Chalk in the Berkshire Downs of southern England, already the subject of intensive hydrogeological investigations under the LOCAR research programme (Wheater et al., 2007). 
The objectives of the study were fourfold: to determine how the ${ }^{3} \mathrm{H} /{ }^{3} \mathrm{He}$ method performed in the Chalk, an important aquifer in the southern UK; to assess different sampling strategies; to gain a better understanding of 'excess air' (Heaton and Vogel, 1981) in Chalk groundwaters; and to evaluate the performance of diffusion cell samplers versus pumped samples (diffusion samplers can be used in situations where pumping is undesirable or impractical, and also allow simpler handling in the laboratory because no degassing step is required: Gardner and Solomon, 2009).

\section{BACKGROUND}

\section{The ${ }^{3} \mathrm{H} /{ }^{3} \mathrm{He}$ groundwater dating method}

The radio-isotope ${ }^{3} \mathrm{H}$ decays to the daughter product ${ }^{3} \mathrm{He}$, emitting a $\beta$-particle in the process, with a halflife of $12.32 \mathrm{yrs}$ (Lucas and Unterweger, 2000). The dating equation takes the following form:

$$
\mathrm{t}=\lambda^{-1} \ln \left[\left({ }^{3} \mathrm{He} *{ }^{3} \mathrm{H}\right)+1\right]
$$

where $\mathrm{t}=$ age in years

$\lambda=\ln 2 / 12.32$ (i.e. the decay constant for $^{3} \mathrm{H}$ )

${ }^{3} \mathrm{H}=$ residual activity in tritium units (TU, i.e. $1{ }^{3} \mathrm{H}$ in $10^{18} \mathrm{H}$ )

${ }^{3} \mathrm{He}^{*}=$ equivalent activity in TU of decay-produced ${ }^{3} \mathrm{He}$.

The ratio of ${ }^{3} \mathrm{H} /{ }^{3} \mathrm{He}$ in a sample of groundwater has the potential to be a sensitive dating method, immune to any contamination or other modifying processes. However, this assumes that the produced ${ }^{3} \mathrm{He}$ remains in the groundwater, and that this ${ }^{3} \mathrm{He}$ can be distinguished from any background ${ }^{3} \mathrm{He}$ already present (Schlosser, 1992). Provided a groundwater is not exposed to the atmosphere, it is likely that ${ }^{3} \mathrm{He}$ will remain in solution. Sources of background ${ }^{3} \mathrm{He}$ include the atmosphere, the excess air (EA) usually present in groundwaters due to the forcible solution of air bubbles (Heaton and Vogel, 1981), nucleogenic reactions with ${ }^{6} \mathrm{Li}$ (Andrews et al., 1989), and mantle sources of helium (Lupton et al., 1977). In the case 
of the present study, the last two sources can be ruled out as significant contributors owing to the low $\mathrm{Li}$ content of the Chalk and the thick continental crust underlying Britain. Atmospheric and EA sources can be accounted for by measurement of the ${ }^{3} \mathrm{He} /{ }^{4} \mathrm{He}$ ratio in the sample, combined with knowledge of the EA contribution derived from measurement of the concentrations of the noble gases neon (Ne), argon (Ar), krypton (Kr) and xenon (Xe) (Aeschbach-Hertig et al., 2000). Since concentrations of Ar, Kr and Xe are highly temperature-dependent, their measurement also allows the calculation of recharge temperature, after any excess air contributions have been taken into account (Aeschbach-Hertig and Solomon, 2013).

\section{Study area}

The Chalk carbonate aquifer is an important resource in southern and eastern England, supplying about $70 \%$ of the water used for public consumption. However, its unusual lithology (highly microporous but extensively fractured: Price, 1987) results in a hydraulic behaviour that can be difficult to predict. For example, observations in the unsaturated zone suggest low rates of water movement (Smith et al., 1970; Lee et al., 2006; van den Daele et al., 2007), while the Chalk's sub-karstic nature can under certain conditions promote very rapid flow in the saturated zone (Banks et al., 1995; Maurice et al., 2010, 2012). Tritium has been measured in various Chalk aquifer studies but only interpreted in a qualitative way regarding groundwater ages (e.g. Downing et al., 1978; Lloyd and Howard, 1979). However, the alternative age tracers CFCs and particularly $\mathrm{SF}_{6}$ have been used more quantitatively (Darling et al., 2005; Gooddy et al., 2006).

The area chosen for the ${ }^{3} \mathrm{H} /{ }^{3} \mathrm{He}$ study (Fig. 1) is a part of the Berkshire Downs already investigated by groundwater dating and other hydrogeochemical techniques (Darling et al., 2012b and references therein). With the existence of recharge areas on the hills and discharge zones in the valleys (Wheater et al., 2007), the area was considered to be an ideal test-bed for the application of the technique. 


\section{SAMPLING AND ANALYSIS}

A total of six boreholes and six springs were sampled across the investigation area, plus five piezometer nests at a dedicated research site at Boxford (for locations see Fig. 1). Boreholes in the Chalk are generally unlined except for superficial soil and sediments (and sometimes parts of the Upper Chalk) which are screened out (see e.g. Maurice et al., 2012). Groundwater discharges into the boreholes predominantly from discrete fractures in the Chalk.

The Boxford research site was set up primarily to study river-groundwater interaction. However, subsequent investigations revealed that this was only limited, with little effect on the underlying groundwater (Allen et al, 2010). The site includes a line of nested piezometers stretching $\sim 250 \mathrm{~m}$ from the immediate vicinity of the River Lambourn up the adjacent slope to a ground level $\sim 25 \mathrm{~m}$ above the river level (Fig. 2a). Piezometers were usually completed in pairs ( $1=$ lower, $2=$ upper, Fig. 2b) within single boreholes, isolated with bentonite backfill. However, in the case of Nest G the reduced access tube diameter for G2 meant that only the top piezometer (G3) and the annulus below $45 \mathrm{~m}$ beneath ground level (G1) could be sampled.

For the boreholes and springs across the investigation area, active sampling was carried out by collection of pumped waters into $1 \mathrm{~L}$ bottles (for ${ }^{3} \mathrm{H}$ analysis) and $1 \mathrm{~m}$ long $10 \mathrm{~mm}$ OD clamped copper tubes (for noble gas analysis). Passive sampling (for noble gases only) was performed by deployment of diffusion samplers (Fig. 3) in boreholes (hung at depths selected for each borehole) or springs, for a minimum of 24 hours to allow for equilibration. (See Aeschbach-Hertig and Solomon, 2013 for further information on noble gas sampling techniques.) Diffusion samplers were normally deployed in pairs. Measurements of total dissolved gas pressure (TDGP), necessary for calculating diffusion cell noble gas analyses, were made using a Hach Surveyor 4a probe suspended either at the relevant depths in each borehole or in the spring pool. This normally required $\sim 20$ min to reach a constant reading. Samples for $\mathrm{SF}_{6}$ were also 
collected for most sites, by filling a $500 \mathrm{~mL}$ glass bottle via tubing while the vessel was immersed in a bucket of the same water.

For the Boxford piezometer study, only pumped samples sealed into copper tubes were collected owing to the potential difficulties with deploying diffusion samplers through narrow access tubes. Four out of the ten piezometers were sampled in duplicate.

All ${ }^{3} \mathrm{H}$ and noble gas preparation and measurements were carried out by the laboratories of the Isotope Hydrology Section of the IAEA in Vienna. Water samples for ${ }^{3} \mathrm{H}$ measurement were prepared by electrolytic enrichment followed by decay counting, based on the method of Allen et al. (1966). Water samples for noble gas measurement were degassed, then the gas fractions separated by various cryotrapping steps to provide $\mathrm{He}$ for isotope measurement on a magnetic sector mass spectrometer, and $\mathrm{Ne}$, $\mathrm{Ar}, \mathrm{Kr}$ and $\mathrm{Xe}$ for concentration measurement on quadrupole mass spectrometers (Matsumoto et al., 2017). Diffusion sampler gases were similarly processed but without the degassing step. Measurement precisions are provided in the results tables. Analysis of $\mathrm{SF}_{6}$ was carried out at the Wallingford laboratories of the BGS using a standard purge-and-cryotrap gas chromatography method (e.g. Bullister and Weiss, 1988).

\section{RESULTS}

Results from the boreholes and springs shown on Fig. 1 are presented in Table 1. For the noble gases, this table includes only the ${ }^{3} \mathrm{H} /{ }^{3} \mathrm{He}$ ages, modelled excess air concentrations and recharge temperatures. Raw data including $\mathrm{SF}_{6}$ are reported in Supplementary Materials as Table S1.

Results from the nested piezometers at the Boxford research site are provided in Table 2. As with Table 1 only the headline data are presented, with raw data being reported in Table S2. 
The ${ }^{3} \mathrm{H} /{ }^{3} \mathrm{He}$ ages are calculated using EA values modelled on the assumption that the closed-system equilibration (CE) model (Aeschbach-Hertig et al., 2000, 2008) best represents recharge conditions. The calculated ages assume a simple piston flow model of groundwater movement. Calculations were carried out using a spreadsheet program (iNOBLE version 1.0) available from the IAEA (Matsumoto, 2015) and based on a routine developed by Heidelberg University (http://www.iup.uniheidelberg.de/institut/forschung/groups/aquasys/WAH/software.html).

The results are discussed below with reference to the wider Berkshire Downs aquifer and more specifically the Boxford research site.

\section{DISCUSSION}

\section{Sampling method}

Previous experience with clamped copper tube sampling by the IAEA and others over several decades has led to the conclusion that a single tube per sample location is sufficient, provided the sampling has been performed correctly (i.e. with no atmospheric air contamination - see Aeschbach-Hertig and Solomon, 2013). Accordingly, with only rare exceptions, single tube samples were collected for this study. At the time the study commenced, however, the performance of diffusion samplers had been less fully evaluated, so duplicate samples were usually collected. While each diffusion sampler has two sample chambers (Fig. 3; see also Aeschbach-Hertig and Solomon, 2013), normally only one was chosen for analysis, unless the results were anomalous, in which case the contents of the second chamber were analysed. 
The results obtained from diffusion sampler pairs are compared in Fig. 4. Agreement is generally good for ${ }^{3} \mathrm{H} /{ }^{3} \mathrm{He}$ ages, with only 2 out of $19(10.5 \%)$ of the pairs failing to agree within the error bars (Fig. 4a), which is not significant at the 1-sigma level. Agreement for EA is generally even better (Fig. 4b), but for NGT there is a little more scatter (Fig. 4c). There is no connection between poor agreements for EA and NGT, thus no indication of a common cause. Overall, it is apparent that taking the mean of diffusion pairs, or single results where one sampler has given obviously anomalous results, is an acceptable basis for comparison with pumped samples collected in copper tubes.

A comparison of copper tube and diffusion sampler performance is shown in Fig. 5. There are no clear differences in agreement between borehole and spring categories. For ${ }^{3} \mathrm{H} / \mathrm{He}$ ages (Fig. 5a) approximately one-third of the 17 datapoints fall beyond error of the 1:1 line, but the remaining points are distributed fairly evenly about the line. This suggests that the apparent bias towards older ages shown by five of the pumped samples is actually the result of systematic errors rather than being genuine. EA is also generally comparable (Fig. 5b), though two out of the 16 instances (12.5\%) have large discrepancies apparently attributable to diffusion samples (the duplicates nevertheless agreed well). There is greater scatter in the NGT values (Fig. 5c): excluding the four outliers, the diffusion samples occupy a tighter distribution $\left(8.4-10.5^{\circ} \mathrm{C}\right)$ than the pumped samples $\left(6.0-9.7^{\circ} \mathrm{C}\right)$, which may be due to most of the diffusion data being the mean of duplicate pairs compared to the single analyses from the pumped samples. The plot also indicates a bias towards lower temperatures for the pumped samples by $\sim 1.5^{\circ} \mathrm{C}$. Samples from three sites (Beche Park Woods $79 \mathrm{~m}$, Great Shefford $22.5 \mathrm{~m}$ and Bagnor Cress Beds October 2011) showed consistently large discrepancies between at least two out of the three properties (i.e. age, EA and NGT), suggesting that there was a problem with the sampling or subsequent processing of one or other of the sample types. In general it appears that pumped sample and diffusion cell data compare reasonably well, and that either sampling method is capable of giving satisfactory results for age and EA. Temperature however remains problematic, with the diffusion cell samples giving the more realistic NGTs (see below). 


\section{Excess air and recharge temperatures}

The amount of EA found in groundwaters is considered to be primarily linked to the magnitude of cyclic water level fluctuations in an aquifer (Aeschbach-Hertig et al., 2002). The predominantly low values of EA calculated from the noble gas data for the catchment samples (mean $1.24 \pm 0.59 \mathrm{ccSTP} / \mathrm{kg}$ with outliers removed) were somewhat unexpected for the Chalk, both from the results of Elliot et al. (1999) which averaged $3.13 \pm 1.40 \mathrm{ccSTP} / \mathrm{kg}$ for unconfined groundwaters in the Chalk aquifer to the SE of the present study area, and because the Chalk is a fractured aquifer which undergoes a change in water level of several metres over a typical hydrological year (for example, annual fluctuations of up to $7 \mathrm{~m}$ in the Bradleywood Farm borehole near the centre of the study area: Darling et al., 2012b). The relatively low amounts of EA measured in this study therefore suggest that the mode of recharge at the Chalk water table is largely due to steady matrix flow rather than pulses of fracture flow. (They also have implications for the calculation of $\mathrm{SF}_{6}$ ages because these require correction for EA-derived $\mathrm{SF}_{6}$ : Darling et al., 2012a.) Figure $5 \mathrm{~b}$ indicates only a slight bias towards lower EA values for spring waters; given that these are at the discharge end of the aquifer system they must represent (albeit to varying extents) mixtures of the aquifer as a whole and therefore serve to confirm that the boreholes chosen for sampling are reasonably representative of the aquifer.

Noble gas temperatures are based on measured $\mathrm{Ne}, \mathrm{Ar}, \mathrm{Kr}$ and $\mathrm{Xe}$ concentrations with an iterative correction for any EA contributions (Aeschbach-Hertig and Solomon, 2013). They should reflect the temperature at the point where the saturated zone commences, i.e. at the water table. Unless water tables are particularly shallow or deep, neither of which apply to the study area, seasonal temperature fluctuations should be minimal and NGTs should be close to mean annual air temperature (MAAT). The 30-year MAAT for the region is $\sim 10.0^{\circ} \mathrm{C}$ (UK Meteorological Office data), so NGTs would be expected to average around this figure or perhaps slightly higher to reflect a small geothermal gradient effect. In fact, with two clear outliers discarded, the average diffusion cell NGT for boreholes was $9.2 \pm 0.7^{\circ} \mathrm{C}$ ( eight samples after removal of two outliers), and for springs $9.7 \pm 0.4^{\circ} \mathrm{C}$ ( six samples), thus not 
significantly different from MAAT. (As mentioned earlier, pumped samples gave consistently lower temperatures so have not been used.) The Boxford piezometers gave EA values of $1.36 \pm 0.42 \mathrm{ccSTP} / \mathrm{kg}$ (four outliers excluded, Table 2), not significantly higher than those samples from the boreholes and springs. NGT values averaged $9.7^{\circ} \mathrm{C}$, i.e. close to MAAT, especially considering that all Boxford samples were pumped, but with a significantly larger standard deviation of $\pm 2.4^{\circ} \mathrm{C}$.

\section{Dating Chalk groundwater: boreholes and springs}

With the exception of Great Shefford, the boreholes sampled for the study (Fig. 1) can be regarded as being in the recharge section of the Chalk aquifer. It would therefore be anticipated that they might show some evidence of layering, with younger ages nearer to the water table. In the case of Great Shefford, situated in a valley bottom, a homogeneous well-mixed water column might be expected owing to flow convergence.

The depths in individual boreholes at which diffusion samplers were hung, and which were subsequently pumped at the slowest possible rate $(<5 \mathrm{~L} / \mathrm{min})$ for the collection of copper tube samples, were chosen on the basis of inflow horizons identified by previous solute dilution profile tests (Maurice et al., 2006). Depths are presented in two ways in Table 1: as depth below surface, and as depth below water table.

The measured ${ }^{3} \mathrm{H} /{ }^{3} \mathrm{He}$ ages from Table 1 are plotted in Fig. 6 . Three characteristics are apparent: there are no well-developed trends towards increasing age with depth; most of the ages are $\sim 5$ years or less, including samples from depths in of excess of $20 \mathrm{~m}$ below water table; and the error bars are such that for at least some boreholes, any age structure could be masked.

As already implied, spring discharges represent an integrated sample of groundwater from many potential flowpaths. While they obviously cannot be depth-sampled, they can be sampled seasonally, in this case in May/June and October/November which normally coincide with seasonal high and low spring flows 
respectively, to see whether any significant changes are revealed. Spring data from Table 1 are plotted in Fig. 7. For consistency, only copper tube sample data are normally plotted because diffusion samples were not collected for the last two sampling rounds; however, where copper tube results are clearly anomalous (e.g. excess air from the Kimber sample of May 2011), a diffusion cell result has been substituted. One spring (East Garston) ran dry at low flow, while another (Woolstone Wells) was only sampled at low flow (twice).

Kimber Spring is part of the Blue Pool spring complex which forms the perennial head of the River Pang (Fig. 1), and is considered to tap the largest storage of any of the springs (Darling et al., 2012b). Its higher and relatively unchanging age (Fig. 7a) supports this view. The scarp slope springs (East Ginge, Letcombe Bassett and Woolstone Wells) might be expected to have relatively short flowpaths and hence residence times, and this is indeed reflected in their ${ }^{3} \mathrm{H} /{ }^{3} \mathrm{He}$ ages. East Garston has the lowest flow of any of the springs and presumably has only a very local circulation and low storage.

Of the springs that do show seasonal changes in age (Bagnor Cress Beds, East Ginge and Letcombe Bassett), each shows a tendency towards younger age at high flow (Fig. 7a), suggesting mixing between older baseflow and recent winter-spring recharge. Excess air, on the other hand, shows no consistent seasonal change for these springs (Fig. 7b), so is clearly immune to the mixing indicated by the age data. Indeed, the springs as a whole show little seasonal response in EA, except for Kimber.

The rather low NGTs shown by some samples have already been commented on, and the October 2011 value for Kimber (Fig. 7c) falls into this category: as the oldest of the spring waters, it would be expected to have very little change due to its high storage. This, combined with a low EA value (Fig. 7b) suggests a possible problem with the October 2011 Kimber sample. However in the case of the 'seasonal age' springs of Bagnor Cress Beds, East Ginge and Letcombe Bassett, all show a consistent increase in NGT at high flow. This is more difficult to explain: the greater proportion of recent water indicated by the ${ }^{3} \mathrm{H} /{ }^{3} \mathrm{He}$ 
ages, presumably derived from winter rainfall 'short-circuiting' the spring systems, might be expected to have a cooling rather than warming effect. It may be noted that no consistent seasonal effects on spring chemistry or stable isotopes have previously been observed for discharges from these springs (Darling et al., 2012b).

\section{Dating Chalk groundwater: Boxford research site}

The results for EA, NGT and ${ }^{3} \mathrm{H} /{ }^{3} \mathrm{He}$ age (Table 2) show that agreement between duplicate samples was generally good, though not necessarily for all three properties (e.g. G1). EA values from I2 were anomalously high, which may reflect some aspect of the sampling process in that particular piezometer.

${ }^{3} \mathrm{H} /{ }^{3} \mathrm{He}$ ages (averaged for duplicate samples) are plotted against depth in Fig. 8. While the low age from A2 may have been the consequence of leakage, and there is some uncertainty over what depth interval the G1 sample actually integrates, there are enough 'good' samples to show an apparent depth-age relationship relative to the water. Using the simple piston flow expression of Vogel (1967) whereby:

$$
\mathrm{V}_{0}=\mathrm{Z}_{0} / \mathrm{T} \times \ln \left(\mathrm{Z}_{0} /\left(\mathrm{Z}_{0}-\mathrm{Z}\right)\right.
$$

where $\mathrm{V}_{0}=$ vertical velocity at the water table

$\mathrm{Z}_{0}=$ thickness of the aquifer

$\mathrm{Z}=$ depth below water table

$\mathrm{T}={ }^{3} \mathrm{H} /{ }^{3} \mathrm{He}$ age

and the aquifer is assumed to have an effective thickness below water table of $50 \mathrm{~m}$ (Price et al., 1993), a $\mathrm{V}_{0}$ value of $\sim 3.3 \mathrm{~m} / \mathrm{yr}$ provides the best fit to the data (Fig. 8). 


\section{Comparison with other Chalk groundwater dating studies}

To what extent do the ${ }^{3} \mathrm{H} /{ }^{3} \mathrm{He}$ piston flow ages reported in Tables 1 and 2 accurately describe flow processes in the Chalk? One way of testing this is to compare total tritium (i.e. ${ }^{3} \mathrm{H}$ plus the tritiogenic ${ }^{3} \mathrm{He}$ loss) from this study with $\mathrm{SF}_{6}$ data obtained from the Berkshire Downs aquifer during the study (Table S1) and by Gooddy et al. (2006) for Boxford. Both these age tracers can be regarded as commencing at the water table, i.e. they do not record any unsaturated zone residence time. Fig. 9 shows a co-plot of the data with the $\mathrm{SF}_{6}{ }^{-}{ }^{3} \mathrm{H}$ atmospheric input curve back to 1980. Also shown are two binary mixing trends, for 2014 (lower line) and 2004 (upper line) because the Boxford $\mathrm{SF}_{6}$ data were collected in that year (the Boxford total ${ }^{3} \mathrm{H}$ activities have been decay-corrected back to 2004 values to reflect this).

Approximately one-third of the samples plot on or near the input curve and therefore appear to be predominantly the product of simple piston flow. The other samples fall below the curve, but generally above the appropriate binary mixing lines, indicating the existence of more complex mixing flow processes as might be expected for a multi-porous aquifer like the Chalk. There is no clear distinction between recharge and discharge zones (essentially boreholes and springs) in terms of their indicated mode of flow.

The $3.3 \mathrm{~m} / \mathrm{yr}$ recharge velocity suggested by the Boxford ${ }^{3} \mathrm{H} /{ }^{3} \mathrm{He}$ data can be compared with unsaturated zone studies using ${ }^{3}$ H. From a borehole near Bradleywood Farm (Fig. 1), Smith et al. (1970) established that most ${ }^{3} \mathrm{H}$ in the Chalk travels through the unsaturated zone at a velocity of $\sim 1 \mathrm{~m}$ per year, a rate of water movement since confirmed for the Chalk of southern England by other chemical and isotopic tracers (e.g. Wellings and Bell, 1980; Geake and Foster, 1989). However, while the term 'unsaturated zone' is used in this paper and in many other published studies of the Chalk, it should be noted that it has a somewhat restricted meaning for the Chalk: Vachier et al. (1987) found that, owing to its microporosity, the Chalk matrix is very close to saturation to at least $40 \mathrm{~m}$ above the water table. 
The apparent threefold increase in recharge velocity below the water table suggested by the Boxford data indicates an effective porosity of only $30 \%$ of the typical unsaturated zone microporosity. The reason for this must be the significantly greater importance of fractures as water conduits under fully-saturated conditions (e.g. Price, 1987).

\section{CONCLUSIONS}

The objectives of the study mentioned earlier (testing diffusion cell versus pumped tube sampling, excess air in a multi-porous aquifer, sampling strategies, and dating groundwater in the Chalk ) were realised with varying degrees of success.

The data obtained from pumped samples collected into copper tubes when compared against the data from diffusion cell samplers gave generally similar results for excess air and ${ }^{3} \mathrm{H} /{ }^{3} \mathrm{He}$ age. Agreement for noble gas temperatures (NGTs) was less good, with a fair amount of scatter for both techniques, though the diffusion data were nearer the expected $10^{\circ} \mathrm{C}$ mean for shallow groundwater.

Excess air in the Chalk was generally found to be low, with a mean of $\sim 1.3 \mathrm{ccSTP} / \mathrm{kg}$. For an aquifer subject to relatively large seasonal changes in water table elevation, this was a somewhat unexpected finding and implies that recharge through the microporous matrix predominates over recharge via the fracture network.

Neither the suspension of diffusion samplers nor the use of slow pumping at previously-identified inflow horizons were effective at revealing any age structure in the water column of open Chalk boreholes. However, piezometer samples with restricted depth intervals did show evidence of age layering. 
Conceivably the use of inflatable packers (beyond the resources available to the present study) would reveal similar layering in the boreholes.

In terms of dating groundwaters in the Chalk aquifer, the ${ }^{3} \mathrm{H} /{ }^{3} \mathrm{He}$ method yielded ages which were low in comparison with unsaturated zone transit times. Yet the average age of the spring waters exceeded that of the boreholes, which is in accordance with the expected recharge-discharge relationship for an aquifer. When plotted against another age indicator $\left(\mathrm{SF}_{6}\right)$, total tritium $\left({ }^{3} \mathrm{H}+\right.$ tritiogenic ${ }^{3} \mathrm{He}$ equivalent $)$ revealed cases of apparent piston flow as well as the mixing that might have been expected to dominate the hydrogeology of a fractured aquifer like the Chalk.

Acknowledgments - Thanks are due to Barry Townsend (BGS) for providing strong support in the field, to Daniela Brummer, Philipp Klaus and Chinmaya Sambandam (IAEA) for tritium analysis, and to referees Tim Atkinson and Anonymous for their valuable comments on the original manuscript. WGD, DCG and DW publish with the permission of the Executive Director, British Geological Survey (NERC). 


\section{REFERENCES}

Aeschbach-Hertig, W. and Solomon, D. K. (2013) Noble gas thermometry in groundwater hydrology. In The noble gases as geochemical tracers (P. Burnard, ed.), Springer, 81-122.

Aeschbach-Hertig, W., Peeters, F., Beyerle, U. and Kipfer, R. (2000) Palaeotemperature reconstruction from noble gases in groundwater accounting for equilibration with entrapped air, Nature 405, 1040-1044.

Aeschbach-Hertig, W., Beyerle, U., Holocher, J., Peeters, F. and Kipfer, R. (2002) Excess air in groundwater as a potential indicator of past environmental changes. Study of Environmental Change Using Isotope Techniques. Proc. Symp. IAEA, Vienna, 174-183.

Aeschbach-Hertig, W., El-Gamal, H., Wieser, M. and Palcsu, L. (2008). Modeling excess air and degassing in groundwater by equilibrium partitioning with a gas phase. Water Resources Research 44, DOI: 10.1029/2007WR006454.

Allen, D. J., Darling, W. G., Gooddy, D. C., Lapworth, D. J., Newell, A. J., Williams, A. T., Allen, D. and Abesser, C. (2010) Interaction between groundwater, the hyporheic zone and a Chalk stream: a case study from the River Lambourn, UK. Hydrogeol. J. 18, 1431-2174.

Allen, R. A., Smith, D. B., Otlet, R. L. and Rawson, D. S. (1966) Low-level tritium measurements in water. Nuclear Instruments and Methods 45, 61-71.

Andrews, J. N., Davis, S. N., Fabryka-Martin, J., Fontes, J. C., Lehmann, B. E., Loosli, H. H., Michelot, J. L., Moser, H., Smith, B. and Wolf, M. (1989) The in situ production of radioisotopes in rock matrices with particular reference to the Stripa granite. Geochimica et Cosmochimica Acta 53(8), pp.1803-1815.

Banks, D., Davies, C. and Davies, W. (1995) The Chalk as a karstic aquifer: evidence from a tracer test at Stanford Dingley, Berkshire, UK. Quarterly J. Eng. Geol. and Hydrogeol. 28, S31-S38.

Busenberg, E., and Plummer, L. N. (2000) Dating young groundwater with sulfur hexafluoride: Natural and anthropogenic sources of sulfur hexafluoride. Water Resour. Res. 36, 3011-3030. 
Bullister, J. L. and Weiss, R. F. (1988) Determination of $\mathrm{CCl}_{3} \mathrm{~F}$ and $\mathrm{CCl}_{2} \mathrm{~F}_{2}$ in seawater and air. Deep Sea Research Part A. Oceanographic Research Papers 35, 839-853.

Darling, W. G., Morris, B. L., Stuart, M. E. and Gooddy, D. C. (2005) Groundwater age indicators from public supplies tapping the Chalk aquifer of Southern England. Water and Environ. J. 19, 30-40.

Darling, W. G., Gooddy, D. C., MacDonald, A. M. and Morris, B. L. (2012a) The practicalities of using CFCs and $\mathrm{SF}_{6}$ for groundwater dating and tracing. Appl. Geochem. 27, 1688-1697.

Darling, W. G., Gooddy, D. C., Morris, B. L. and Peach, D. W. (2012b) The hydrochemistry of a Chalk aquifer during recovery from drought. Quarterly J. Eng. Geol. and Hydrogeol. 45, 473-486.

Downing, R.A., Smith, D.B. \& Warren, S.C. (1978) Seasonal variations of tritium and other constituents in groundwater in the Chalk near Brighton, England. J. Instn Wat. Engrs Scient. 32, 123-136.

Elliot, T., Andrews, J. N., \& Edmunds, W. M. (1999) Hydrochemical trends, palaeorecharge and groundwater ages in the fissured Chalk aquifer of the London and Berkshire Basins, UK. Appl. Geochem. 14, 333-363.

Eriksson, E. (1965) An account of the major pulses of tritium and their effects in the atmosphere. Tellus $17,118-130$.

Gardner, P., and Solomon, D. K. (2009) An advanced passive diffusion sampler for the determination of dissolved gas concentrations. Water Resour. Res., 45, W06423 1-12.

Geake, A. K., \& Foster, S. S. (1989) Sequential isotope and solute profiling in the unsaturated zone of British Chalk. Hydrol. Sci. J. 34, 79-95.

Gooddy, D. C., Darling, W. G., Abesser, C. and Lapworth, D. J. (2006) Using chlorofluorocarbons (CFCs) and sulphur hexafluoride $\left(\mathrm{SF}_{6}\right)$ to characterise groundwater movement and residence time in a lowland Chalk catchment. J. Hydrol. 330, 44-52.

Heaton, T. H. E. and Vogel, J. C. (1981) “Excess air” in groundwater. J. Hydrol. 50, 201-216. 
Lee, L. J. E., Lawrence, D. S. L. and Price, M. (2006) Analysis of water-level response to rainfall and implications for recharge pathways in the Chalk aquifer, SE England. Journal of Hydrology 330, 604620.

Lloyd, J. W., \& Howard, K. W. F. (1979). Environmental isotope studies related to groundwater flow and saline encroachment in the Chalk aquifer of Lincolnshire, England. Isotope Hydrology 1978, Vol 1. Proc. Symp. IAEA, Vienna, 311-323.

Lucas, L. L. and Unterweger, M. P. (2000) Comprehensive review and critical evaluation of the half-life of tritium. Journal of Research of the National Institute of Standards and Technology 105, 541-549.

Lupton, J. E., Weiss, R. F. and Craig, H. (1977) Mantle helium in the Red Sea brines. Nature 266, $244-$ 246.

Matsumoto, T. (2015) A VBA-Excel program for noble gas data analysis for groundwater dating and recharge temperature. In International Symposium on Isotope Hydrology, Book of Extended Synopses, Poster Session 1, 243.

Matsumoto, T., Solomon, D. K., Araguas-Araguas, L. and Aggarwal, P. (2017) The IAEA's coordinated research project on "Estimation of Groundwater Recharge and Discharge by Using the Tritium, Helium-3 Dating Technique”. Geochemical Journal51, 385-390.

Maurice, L. D., Atkinson, T. C., Barker, J. A., Williams, A. T. and Gallagher, A. J. (2006) The nature and distribution of flowing features in a weakly karstified porous limestone aquifer. J. Hydrol. 438/439, $3-15$.

Maurice, L., Atkinson, T. C., Williams, A. T., Barker, J. A. and Farrant, A. R. (2010) Catchment scale tracer testing from karstic features in a porous limestone. Journal of Hydrology 389, 31-41.

Maurice, L. D., Atkinson, T. C., Barker, J. A., Williams, A. T. and Gallagher, A. J. (2012). The nature and distribution of flowing features in a weakly karstified porous limestone aquifer. Journal of Hydrology $438,3-15$. 
Münnich, K. O., Roether, W. and Thilo, L. (1967) Dating of groundwater with tritium and ${ }^{14}$ C. Isotopes in Hydrology. Proc. Symp. IAEA, Vienna, 305-320.

Newman, B. D., Osenbrück, K., Aeschbach-Hertig, W., Solomon, D. K., Cook, P., Różański, K. and Kipfer, R. (2010) Dating of 'young' groundwaters using environmental tracers: advantages, applications, and research needs. Isotopes in Environ. and Health Studies 46, 259-278.

Oster, H., Sonntag, C. and Münnich, K. O. (1996) Groundwater age dating with chlorofluorocarbons. Water Resour. Res. 37, 2989-3001.

Price, M. (1987) Fluid flow in the Chalk of England. Geol. Soc. Lond., Spec. Publs 34, 141-156.

Price, M., Downing, R. A. and Edmunds, W. M. (1993) The Chalk as an aquifer. In: Downing, R. A., Price, M. and Jones, G. P. (eds) The Hydrogeology of the Chalk of North-West Europe. Oxford Science Publications, Clarendon Press, Oxford, 35-58.

Schlosser, P. (1992) Tritium $/{ }^{3} \mathrm{He}$ dating of waters in natural systems. Isotopes of Noble Gases as Tracers in Environmental Studies. Proc. Symp. IAEA, Vienna, 123-145.

Smith, D. B., Wearn, P. L., Richards, H. J. and Rowe, P. C. (1970) Water movement in the unsaturated zone of high and low permeability strata by measuring natural tritium. Isotope Hydrology. Proc. Symp. IAEA, Vienna, 259-270.

Tolstikhin, I. N. and Kamenskiy, I. L. (1969) Determination of ground-water ages by the T- ${ }^{3}$ He Method. Geochemistry International 6, 810-811.

Vachier, P., Dever, L. and Fontes, J. C. (1987) Mouvements de l'eau dans la zone non saturée et alimentation de la nappe de la Craie de Champagne (France). Isotope Techniques in Water Resources Development. Proc. Symp. IAEA, Vienna, 367-379.

Van den Daele, G. F., Barker, J. A., Connell, L. D., Atkinson, T. C., Darling, W. G. and Cooper, J. D. (2007). Unsaturated flow and solute transport through the Chalk: Tracer test and dual permeability modelling. Journal of Hydrology 342, 157-172. 
Visser, A., Broers, H. P., Purtschert, R., Sültenfuss, J. and Jonge, M. (2013) Groundwater age distributions at a public drinking water supply well field derived from multiple age tracers $\left({ }^{85} \mathrm{Kr},{ }^{3} \mathrm{H} /{ }^{3} \mathrm{He}\right.$, and $\left.{ }^{39} \mathrm{Ar}\right)$. Water Resour. Res. 49, 7778-7796.

Vogel, J. C. (1967) Investigation of groundwater flow with radiocarbon. In Isotopes in Hydrology, Vienna, 355-368.

Wellings, S. R. and Bell, J. P. (1980) Movement of water and nitrate in the unsaturated zone of Upper Chalk near Winchester, Hants., England. J. Hydrol. 48, 119-136.

Wheater, H. S., Peach, D. and Binley, A. (2007) Characterising groundwater-dominated lowland catchments: the UK Lowland Catchment Research Programme (LOCAR). Hydrology and Earth System Sciences Discussions, 11, 108-124. 
TABLES 
Table 1. Excess air concentration, noble gas temperature, ${ }^{3} \mathrm{H} /{ }^{3} \mathrm{He}$ and $\mathrm{SF}_{6}$ ages for borehole and spring samples from the Chalk aquifer of the Berkshire Downs. The data on which these are based are provided in Table S1 of the Supplementary Materials for this paper.

\begin{tabular}{|c|c|c|c|c|c|c|c|c|c|c|c|c|c|c|c|}
\hline Date/Location & $\begin{array}{c}\begin{array}{c}\text { Depth bwt } \\
\text { m }\end{array} \\
\end{array}$ & $\begin{array}{c}\text { USZ } \\
\mathrm{m}\end{array}$ & Type & $\begin{array}{l}\text { Excess air } \\
\text { ccSTP/kg }\end{array}$ & $\begin{array}{c}\text { Noble gas temp } \\
{ }^{\circ} \mathrm{C}\end{array}$ & $\begin{array}{c}{ }^{3} \mathrm{H}^{3} \mathrm{He} \text { age } \\
\mathrm{yrs}\end{array}$ & $\begin{array}{c}\mathrm{SF}_{6} \text { age } \\
\mathrm{yrs}\end{array}$ & Date/Location & $\begin{array}{c}\text { Depth bwt } \\
\mathrm{m}\end{array}$ & $\begin{array}{c}\text { USZ } \\
\mathrm{m}\end{array}$ & Type & $\begin{array}{l}\text { Excess air } \\
\text { ccSTP/kg }\end{array}$ & $\begin{array}{c}\text { Noble gas temp } \\
{ }^{\circ} \mathrm{C}\end{array}$ & $\begin{array}{c}{ }^{3} \mathrm{H}^{3} \mathrm{He} \text { age } \\
\mathrm{yrs}\end{array}$ & $\begin{array}{c}\mathrm{SF}_{6} \text { age } \\
\text { yrs }\end{array}$ \\
\hline May 2011 & & & & & & & & Oct-Nov 2012 (contd) & & & & & & & \\
\hline Bottom Barn 30m & 3.0 & 27 & $P$ & $2.27 \pm 0.05$ & $8.07 \pm 0.11$ & $2.0 \pm 0.9$ & $15.9 \pm 1.1$ & Brightwalton Common 88.5m & 13.9 & 74.6 & D & $0.00 \pm 0.03$ & $60.7 \pm 1.22$ & $2.4 \pm 1.3$ & \\
\hline Bottom Barn 30m & 3.0 & & D & $1.90 \pm 0.07$ & $8.40 \pm 0.10$ & $0.0 \pm 0.5$ & & Brightwalton Common 88.5m & 13.9 & & D & $0.00 \pm 0.01$ & $94.4 \pm 0.41$ & $0.0 \pm 0.1$ & $6.2 \pm 1.0$ \\
\hline Bottom Barn 34m & 7.0 & & $P$ & $1.44 \pm 0.05$ & $8.85 \pm 0.17$ & $0.0 \pm 0.5$ & $15.6 \pm 1.1$ & Cow Down $78.5 \mathrm{~m}$ & 0.7 & 77.8 & $P$ & $45.2 \pm 0.55$ & $7.23 \pm 0.04$ & $19.2 \pm 6.5$ & \\
\hline Bottom Barn 34m & 7.0 & & D & $2.00 \pm 0.04$ & $8.43 \pm 0.10$ & $0.0 \pm 1.0$ & & Cow Down $78.5 \mathrm{~m}$ & 0.7 & & D & $40.3 \pm 1.01$ & $13.7 \pm 0.12$ & $16.7 \pm 6.0$ & \\
\hline Bottom Barn 34m & 7.0 & & D & $2.00 \pm 0.04$ & $8.28 \pm 0.13$ & $0.0 \pm 0.4$ & & Cow Down $78.5 \mathrm{~m}$ & 0.7 & & D & $2.27 \pm 0.07$ & $11.2 \pm 0.12$ & $0.0 \pm 3.9$ & \\
\hline Bottom Barn 40m & 13.0 & & $\mathrm{P}$ & $2.15 \pm 0.04$ & $7.27 \pm 0.08$ & $0.8 \pm 0.8$ & $15.9 \pm 1.1$ & Cow Down $88.5 \mathrm{~m}$ & 10.7 & & $P$ & $n / a \quad n / a$ & $n / a \quad n / a$ & $0.9 \pm 0.4$ & $10.9 \pm 1.0$ \\
\hline Bottom Barn 40m & 13.0 & & D & $18.2 \pm 0.28$ & $9.88 \pm 0.10$ & $1.6 \pm 1.4$ & & Cow Down $88.5 \mathrm{~m}$ & 10.7 & & $\mathrm{D}$ & $32.7 \pm 1.05$ & $10.3 \pm 0.12$ & $18.1 \pm 6.2$ & \\
\hline Bottom Barn 40m & 13.0 & & D & $19.5 \pm 0.35$ & $9.69 \pm 0.11$ & $2.4 \pm 1.6$ & & Cow Down 88.5m & 10.7 & & $\mathrm{D}$ & $21.3 \pm 0.54$ & $9.52 \pm 0.11$ & $11.9 \pm 7.8$ & \\
\hline Great Shefford 4m & 3.2 & 0.8 & D & $1.75 \pm 0.06$ & $9.08 \pm 0.11$ & $0.0 \pm 0.8$ & & May 2011 & & & & & & & \\
\hline Great Shefford $4 \mathrm{~m}$ & 3.2 & & D & $0.11 \pm 0.00$ & $8.52 \pm 0.16$ & $0.0 \pm 0.7$ & & Bagnor Cress Beds & spring & $\mathrm{n} / \mathrm{a}$ & $\mathrm{P}$ & $0.40 \pm 0.01$ & $8.53 \pm 0.09$ & $5.4 \pm 0.5$ & $20.4 \pm 1.3$ \\
\hline Great Shefford $14 \mathrm{~m}$ & 13.2 & & $\mathrm{P}$ & $1.50 \pm 0.05$ & $7.06 \pm 0.08$ & $0.4 \pm 1.2$ & $14.7 \pm 1.1$ & Bagnor Cress Beds & & & D & $0.75 \pm 0.03$ & $9.73 \pm 0.15$ & $3.5 \pm 1.2$ & \\
\hline Great Shefford 20m & 19.2 & & $P$ & $1.81 \pm 0.03$ & $5.97 \pm 0.05$ & $6.5 \pm 1.6$ & $21.4 \pm 1.3$ & Bagnor Cress Beds & & & D & $0.91 \pm 0.02$ & $9.65 \pm 0.22$ & $5.4 \pm 1.1$ & \\
\hline Great Shefford 20m & 19.2 & & D & $1.84 \pm 0.04$ & $9.08 \pm 0.10$ & $7.8 \pm 2.7$ & & East Garston & spring & $\mathrm{n} / \mathrm{a}$ & $\mathrm{P}$ & $0.90 \pm 0.03$ & $9.08 \pm 0.10$ & $2.0 \pm 0.8$ & $17.9 \pm 1.2$ \\
\hline Great Shefford 20m & 19.2 & & D & $1.45 \pm 0.02$ & $8.89 \pm 0.06$ & $0.0 \pm 1.3$ & & East Garston & & & D & $0.94 \pm 0.02$ & $9.66 \pm 0.15$ & $1.8 \pm 1.4$ & \\
\hline Great Shefford $22.5 \mathrm{~m}$ & 21.7 & & $P$ & $1.99 \pm 0.03$ & $7.34 \pm 0.10$ & $7.3 \pm 2.4$ & $27.1 \pm 1.7$ & East Garston & & & $\mathrm{D}$ & $1.17 \pm 0.03$ & $9.43 \pm 0.13$ & $0.0 \pm 0.7$ & \\
\hline Great Shefford $22.5 \mathrm{~m}$ & 21.7 & & D & $0.26 \pm 0.01$ & $17.1 \pm 0.13$ & $0.0 \pm 0.1$ & & Kimber & spring & $\mathrm{n} / \mathrm{a}$ & $P$ & $102 \pm 1.40$ & $11.4 \pm 0.08$ & $15.3 \pm 1.0$ & $18.7 \pm 1.2$ \\
\hline Great Shefford $22.5 \mathrm{~m}$ & 21.7 & & D & $0.00 \pm 0.03$ & $19.0 \pm 0.12$ & $0.0 \pm 0.4$ & & Kimber & & & D & $141 \pm 1.80$ & $11.7 \pm 0.05$ & $10.9 \pm 1.8$ & \\
\hline Grumble Bottom 22m & 4.5 & 17.5 & $\mathrm{P}$ & $1.20 \pm 0.02$ & $8.37 \pm 0.08$ & $5.1 \pm 0.7$ & $13.6 \pm 1.1$ & Kimber & & & $\mathrm{D}$ & $1.79 \pm 0.06$ & $9.07 \pm 0.17$ & $10.4 \pm 1.5$ & \\
\hline Grumble Bottom 22m & 4.5 & & D & $1.49 \pm 0.06$ & $9.31 \pm 0.15$ & $4.9 \pm 1.1$ & & Oct 2011 & & & & & & & \\
\hline Grumble Bottom 22m & 4.5 & & D & $1.04 \pm 0.06$ & $9.40 \pm 0.20$ & $5.4 \pm 1.0$ & & Bagnor Cress Beds & spring & $\mathrm{n} / \mathrm{a}$ & $\mathrm{P}$ & $0.40 \pm 0.01$ & $8.01 \pm 0.12$ & $8.6 \pm 1.4$ & $22.8 \pm 1.3$ \\
\hline Grumble Bottom 28m & 10.5 & & $P$ & $1.39 \pm 0.03$ & $9.05 \pm 0.10$ & $4.4 \pm 0.6$ & $14.4 \pm 1.1$ & Bagnor Cress Beds & & & D & $0.91 \pm 0.03$ & $9.23 \pm 0.15$ & $6.5 \pm 1.4$ & \\
\hline Grumble Bottom 28m & 10.5 & & D & $1.33 \pm 0.03$ & $9.46 \pm 0.14$ & $3.9 \pm 1.5$ & & Bagnor Cress Beds & & & D & $0.85 \pm 0.04$ & $9.54 \pm 0.25$ & $4.5 \pm 1.4$ & \\
\hline Grumble Bottom 28m & 10.5 & & D & $1.49 \pm 0.05$ & $9.26 \pm 0.17$ & $3.7 \pm 0.4$ & & Kimber & spring & $\mathrm{n} / \mathrm{a}$ & $\mathrm{P}$ & $1.40 \pm 0.03$ & $7.37 \pm 0.13$ & $14.4 \pm 1.9$ & $28.8 \pm 1.7$ \\
\hline Grumble Bottom 40m & 22.5 & & $\mathrm{P}$ & $107 \pm 1.00$ & $12.4 \pm 0.04$ & $5.0 \pm 0.7$ & $16.3 \pm 1.1$ & Kimber & & & $\mathrm{D}$ & $1.46 \pm 0.03$ & $9.63 \pm 0.11$ & $12.6 \pm 1.8$ & \\
\hline Grumble Bottom 40m & 22.5 & & D & $1.58 \pm 0.05$ & $9.13 \pm 0.11$ & $5.2 \pm 1.2$ & & Kimber & & & D & $1.47 \pm 0.04$ & $9.59 \pm 0.14$ & $10.9 \pm 2.4$ & \\
\hline Grumble Bottom 40m & 22.5 & & D & $1.16 \pm 0.02$ & $8.11 \pm 0.08$ & $5.1 \pm 0.9$ & & $\begin{array}{l}\text { Woolstone Wells } \\
\text { Woolstone Wells }\end{array}$ & spring & $\mathrm{n} / \mathrm{a}$ & $\begin{array}{l}\mathrm{P} \\
\mathrm{D}\end{array}$ & $\begin{array}{l}0.42 \pm 0.01 \\
0.49 \pm 0.01\end{array}$ & $\begin{array}{l}6.93 \pm 0.06 \\
9.00 \pm 0.12\end{array}$ & $\begin{array}{l}0.0 \pm 1.9 \\
2.6 \pm 1.9\end{array}$ & $17.8 \pm 1.2$ \\
\hline Oct-Nov 2012 & & & & & & & & Woolstone Wells & & & D & $0.83 \pm 0.04$ & $9.75 \pm 0.12$ & $0.3 \pm 1.2$ & \\
\hline Beche Park Wood 79m & 4.0 & 75 & $\mathrm{P}$ & $0.91 \pm 0.04$ & $6.76 \pm 0.12$ & $7.8 \pm 1.9$ & & Oct-Nov 2012 & & & & & & & \\
\hline Beche Park Wood 79m & 4.0 & & D & $1.25 \pm 0.04$ & $9.18 \pm 0.15$ & $2.6 \pm 2.5$ & & East Ginge & spring & $\mathrm{n} / \mathrm{a}$ & $P$ & $1.86 \pm 0.05$ & $8.16 \pm 0.12$ & $4.6 \pm 1.9$ & $17.6 \pm 1.2$ \\
\hline Beche Park Wood 79m & 4.0 & & D & $1.07 \pm 0.03$ & $8.52 \pm 0.13$ & $2.2 \pm 2.0$ & & Letcombe Bassett & spring & $n / a$ & $\mathrm{P}$ & $1.32 \pm 0.03$ & $8.44 \pm 0.13$ & $4.6 \pm 2.2$ & $16.5 \pm 1.2$ \\
\hline Beche Park Wood 89m & 14.0 & & D & $0.00 \pm 0.02$ & $14.5 \pm 0.23$ & $0.0 \pm 0.6$ & $10.1 \pm 1.0$ & Woolstone Wells & spring & $\mathrm{n} / \mathrm{a}$ & $\mathrm{P}$ & $0.33 \pm 0.01$ & $7.89 \pm 0.11$ & $4.3 \pm 1.4$ & $17.2 \pm 1.2$ \\
\hline Beche Park Wood 89m & 14.0 & & D & $1.47 \pm 0.04$ & $8.89 \pm 0.12$ & $1.2 \pm 1.8$ & & Jun 2013 & & & & & & & \\
\hline Brightwalton Common $78.5 \mathrm{~m}$ & 3.9 & 74.6 & D & $0.73 \pm 0.02$ & $8.84 \pm 0.17$ & $0.0 \pm 1.4$ & & East Ginge & spring & $\mathrm{n} / \mathrm{a}$ & $\mathrm{P}$ & $95.2 \pm 0.70$ & $9.42 \pm 0.03$ & $1.2 \pm 1.0$ & \\
\hline Brightwalton Common 78.5m & 3.9 & & D & $1.02 \pm 0.03$ & $9.10 \pm 0.12$ & $0.0 \pm 3.6$ & & Letcombe Bassett & spring & $n / a$ & $\mathrm{P}$ & $1.20 \pm 0.03$ & $9.11 \pm 0.14$ & $0.0 \pm 1.6$ & \\
\hline
\end{tabular}

bwt - below water table USZ - unsaturated zone thickness $\quad P$ - pumped copper tube $\quad D$ - diffusion cell sampler n/a - not applicable 
Table 2. Excess air concentration, noble gas temperature and ${ }^{3} \mathrm{H} /{ }^{3} \mathrm{He}$ age from piezometers at the Boxford research site. The data on which these are based are provided in Table S2 of the Supplementary Materials for this paper. $\mathrm{SF}_{6}$ ages based on data from Gooddy et al. (2006).

\begin{tabular}{|c|c|c|c|c|c|c|c|c|}
\hline Piezo ID & $\begin{array}{c}\text { W/t Aug-14 } \\
\text { m bgl }\end{array}$ & $\begin{array}{r}\text { Piezom } \\
\text { m b } \\
\text { from }\end{array}$ & $\begin{array}{c}\text { interval } \\
w / t \\
\text { to } \\
\end{array}$ & $\begin{array}{l}\text { Excess air } \\
\mathrm{ccSTP} / \mathrm{kg}\end{array}$ & & $\begin{array}{l}\text { loble gas temp } \\
{ }^{\circ} \mathrm{C}\end{array}$ & $\begin{array}{c}{ }^{3} \mathrm{H} /{ }^{3} \mathrm{He} \text { age } \\
\text { yrs }\end{array}$ & $\begin{array}{c}\text { SF }_{6} \text { age } \\
\text { yrs }\end{array}$ \\
\hline $\mathrm{A} 1$ & 1.01 & 22.05 & 22.55 & $115 \pm 1.01$ & & $11.9 \pm 0.06$ & $8.8 \pm 2.1$ & $12.9 \pm 1.2$ \\
\hline$A 2^{*}$ & 1.09 & 0.00 & 0.70 & $0.00 \pm 0.02$ & & $46.5 \pm 0.66$ & $0.0 \pm 0.1$ & $10.8 \pm 1.5$ \\
\hline E1 & 0.87 & 23.65 & 24.35 & $-t u$ & $b e$ & e $\quad b r o k e$ & $n-$ & $8.8 \pm 1.6$ \\
\hline E2 & 1.16 & 2.55 & 3.25 & $0.94 \pm 0.01$ & & $9.3 \pm 0.10$ & $4.4 \pm 1.6$ & $9.8 \pm 1.4$ \\
\hline G1 & 22.6 & 21.70 & 67.70 & $30.0 \pm 0.64$ & & $11.2 \pm 0.04$ & $7.7 \pm 1.4$ & $25.4 \pm 0.7$ \\
\hline G1 & 22.6 & 21.70 & 67.70 & $1.39 \pm 0.03$ & & $7.3 \pm 0.07$ & $6.5 \pm 1.2$ & \\
\hline G3 & 22.6 & 0.00 & 3.80 & $1.01 \pm 0.03$ & & $8.9 \pm 0.07$ & $2.4 \pm 0.8$ & \\
\hline G3 & 22.6 & 0.00 & 3.80 & $0.97 \pm 0.04$ & & $8.9 \pm 0.07$ & $1.7 \pm 0.7$ & \\
\hline $\mathrm{H} 1$ & 6.80 & 21.20 & 22.20 & $1.48 \pm 0.05$ & & $6.7 \pm 0.07$ & $9.5 \pm 1.3$ & $12.4 \pm 1.4$ \\
\hline $\mathrm{H} 2$ & 6.50 & 14.60 & 15.60 & $1.19 \pm 0.03$ & & $8.2 \pm 0.10$ & $5.5 \pm 1.2$ & $12.9 \pm 1.4$ \\
\hline 11 & 15.7 & 25.75 & 34.25 & $1.85 \pm 0.05$ & & $6.6 \pm 0.12$ & $12.3 \pm 1.1$ & $19.9 \pm 1.1$ \\
\hline 11 & 15.7 & 25.75 & 34.25 & $2.08 \pm 0.03$ & & $11.0 \pm 0.09$ & $9.0 \pm 1.6$ & \\
\hline 12 & 15.7 & 15.60 & 16.60 & $113 \pm 1.91$ & & $12.7 \pm 0.10$ & $8.1 \pm 1.6$ & $20.9 \pm 0.9$ \\
\hline 12 & 15.7 & 15.60 & 16.60 & $120 \pm 0.93$ & & $13.8 \pm 0.06$ & $8.4 \pm 1.4$ & \\
\hline
\end{tabular}

*may have undergone some leakage

$\mathrm{W} / \mathrm{t}$ - water table w/t - water table 
Table S1. Noble gas and $\mathrm{SF}_{6}$ data for groundwaters from the Chalk aquifer of the Berkshire Downs. $F$ and $\chi^{2}$ are respectively the fractionation parameter and sum of the error-weighted deviations between modelled and measured noble gas concentrations for the CE method of EA and NGT calculation (Aeschbach-Hertig et al., 2008).

\begin{tabular}{|c|c|c|c|c|c|c|c|c|c|c|c|c|c|c|}
\hline \multirow[t]{2}{*}{ Date/Location } & \multirow[t]{2}{*}{ Type } & \multirow{2}{*}{$\begin{array}{l}\mathrm{He} \\
\times 10^{-8}\end{array}$} & \multirow{2}{*}{$\begin{array}{c}\mathrm{Ne} \\
\times 10^{-7}\end{array}$} & \multirow{2}{*}{$\begin{array}{c}\mathrm{Ar} \\
-\operatorname{ccsTP} / \mathrm{g} \\
\times 10^{-4}\end{array}$} & \multirow{2}{*}{$\begin{array}{c}\mathrm{Kr} \\
\times 10^{-7}\end{array}$} & ${ }^{x e}$ & $\begin{array}{c}\text { NGT } \\
{ }^{\circ} \mathrm{C}\end{array}$ & $\begin{array}{l}\text { Excess air } \\
\mathrm{ccSTP} / \mathrm{kg}\end{array}$ & $F$ & $\mathrm{x}^{2}$ & & $\begin{array}{l}{ }^{3} \mathrm{H} \\
\mathrm{TU}\end{array}$ & $\begin{array}{c}{ }^{3} \mathrm{H} \text { trit. } \\
\mathrm{TU}\end{array}$ & $\begin{array}{c}\mathrm{SF}_{6} \mathrm{C} \\
\mathrm{fmol} / \mathrm{L}\end{array}$ \\
\hline & & & & & & & & & & & $\times 10^{-6}$ & & & \\
\hline May 2011 & & & & & & & & & & & & & & \\
\hline Bottom Barn 30m & $\mathrm{P}$ & $5.63 \pm 0.04$ & $2.36 \pm 0.01$ & $4.21 \pm 0.05$ & $0.95 \pm 0.02$ & $1.37 \pm 0.07$ & $8.07 \pm 0.11$ & $2.27 \pm 0.05$ & 0.17 & 1.94 & $1.38 \pm 0.01$ & $5.32 \pm 0.28$ & $0.6 \pm 0.3$ & $1.50 \pm 0.10$ \\
\hline Bottom Barn 30m & D & $5.66 \pm 0.09$ & $2.37 \pm 0.03$ & $4.12 \pm 0.07$ & $0.97 \pm 0.02$ & $1.37 \pm 0.11$ & $8.40 \pm 0.10$ & $1.90 \pm 0.07$ & 0.00 & 0.10 & $1.32 \pm 0.01$ & $5.32 \pm 0.28$ & $0.0 \pm 0.2$ & \\
\hline Bottom Barn 34m & $P$ & $5.39 \pm 0.03$ & $2.24 \pm 0.01$ & $4.05 \pm 0.05$ & $0.95 \pm 0.03$ & $1.26 \pm 0.08$ & $8.85 \pm 0.17$ & $1.44 \pm 0.05$ & 0.11 & 1.82 & $1.33 \pm 0.01$ & $6.21 \pm 0.32$ & $0.0 \pm 0.2$ & $1.53 \pm 0.10$ \\
\hline Bottom Barn 34m & D & $5.64 \pm 0.09$ & $2.36 \pm 0.04$ & $4.13 \pm 0.07$ & $0.96 \pm 0.02$ & $1.38 \pm 0.11$ & $8.43 \pm 0.10$ & $2.00 \pm 0.04$ & 0.06 & 0.01 & $1.34 \pm 0.01$ & $2.74 \pm 0.17$ & $0.0 \pm 0.2$ & \\
\hline Bottom Barn 34m & D & $5.62 \pm 0.09$ & $2.39 \pm 0.03$ & $4.13 \pm 0.07$ & $0.97 \pm 0.02$ & $1.47 \pm 0.12$ & $8.28 \pm 0.13$ & $2.00 \pm 0.04$ & 0.00 & 0.52 & $1.34 \pm 0.01$ & $6.21 \pm 0.32$ & $0.0 \pm 0.1$ & \\
\hline Bottom Barn 40m & $\mathrm{P}$ & $5.71 \pm 0.04$ & $2.39 \pm 0.01$ & $4.26 \pm 0.06$ & $0.98 \pm 0.03$ & $1.44 \pm 0.08$ & $7.27 \pm 0.08$ & $2.15 \pm 0.04$ & 0.10 & 0.29 & $1.36 \pm 0.01$ & $5.84 \pm 0.31$ & $0.3 \pm 0.3$ & $1.50 \pm 0.10$ \\
\hline Bottom Barn 40m & D & $5.63 \pm 0.09$ & $2.34 \pm 0.04$ & $4.12 \pm 0.06$ & $0.94 \pm 0.02$ & $1.33 \pm 0.11$ & $9.88 \pm 0.10$ & $18.2 \pm 0.28$ & 0.76 & 0.01 & $1.35 \pm 0.01$ & $6.20 \pm 0.34$ & $0.6 \pm 0.6$ & \\
\hline Bottom Barn 40m & D & $5.72 \pm 0.10$ & $2.38 \pm 0.04$ & $4.17 \pm 0.07$ & $0.96 \pm 0.02$ & $1.34 \pm 0.11$ & $9.69 \pm 0.11$ & $19.5 \pm 0.35$ & 0.75 & 0.03 & $1.36 \pm 0.01$ & $5.84 \pm 0.31$ & $0.8 \pm 0.6$ & \\
\hline Great Shefford 4m & D & $4.61 \pm 0.08$ & $2.34 \pm 0.04$ & $3.97 \pm 0.07$ & $1.00 \pm 0.03$ & $1.32 \pm 0.11$ & $9.08 \pm 0.11$ & $1.75 \pm 0.06$ & 0.00 & 5.85 & $1.35 \pm 0.02$ & $2.81 \pm 0.20$ & $0.0 \pm 0.1$ & \\
\hline Great Shefford 4m & D & $4.77 \pm 0.08$ & $2.04 \pm 0.03$ & $3.93 \pm 0.07$ & $0.96 \pm 0.02$ & $1.29 \pm 0.11$ & $8.52 \pm 0.16$ & $0.11 \pm 0.00$ & 0.00 & 1.21 & $1.30 \pm 0.01$ & $2.81 \pm 0.20$ & $0.0 \pm 0.1$ & \\
\hline Great Shefford $14 \mathrm{~m}$ & $\mathrm{P}$ & $5.76 \pm 0.04$ & $2.28 \pm 0.01$ & $4.22 \pm 0.05$ & $0.99 \pm 0.02$ & $1.44 \pm 0.06$ & $7.06 \pm 0.08$ & $1.50 \pm 0.05$ & 0.13 & 0.08 & $1.26 \pm 0.01$ & $3.25 \pm 0.20$ & $0.1 \pm 0.2$ & $1.61 \pm 0.10$ \\
\hline Great Shefford 20m & $P$ & $6.33 \pm 0.04$ & $2.38 \pm 0.01$ & $4.37 \pm 0.05$ & $1.02 \pm 0.03$ & $1.48 \pm 0.08$ & $5.97 \pm 0.05$ & $1.81 \pm 0.03$ & 0.07 & 0.53 & $1.25 \pm 0.01$ & $2.81 \pm 0.20$ & $1.2 \pm 0.3$ & $0.99 \pm 0.15$ \\
\hline Great Shefford $20 \mathrm{~m}$ & D & $6.87 \pm 0.12$ & $2.35 \pm 0.04$ & $4.04 \pm 0.06$ & $0.98 \pm 0.03$ & $1.31 \pm 0.08$ & $9.08 \pm 0.10$ & $1.84 \pm 0.04$ & 0.00 & 1.74 & $1.17 \pm 0.01$ & $2.81 \pm 0.20$ & $1.5 \pm 0.6$ & \\
\hline Great Shefford 20m & D & $0.00 \pm 0.10$ & $2.28 \pm 0.03$ & $4.05 \pm 0.06$ & $0.94 \pm 0.02$ & $1.43 \pm 0.11$ & $8.89 \pm 0.06$ & $1.45 \pm 0.02$ & 0.00 & 0.34 & $1.21 \pm 0.01$ & $2.81 \pm 0.20$ & $0.0 \pm 0.2$ & \\
\hline Great Shefford $22.5 \mathrm{~m}$ & $\mathrm{P}$ & $6.69 \pm 0.05$ & $2.41 \pm 0.01$ & $4.24 \pm 0.06$ & $0.99 \pm 0.02$ & $1.49 \pm 0.07$ & $7.34 \pm 0.10$ & $1.99 \pm 0.03$ & 0.00 & 0.51 & $1.22 \pm 0.02$ & $2.74 \pm 0.17$ & $1.4 \pm 0.5$ & $0.58 \pm 0.25$ \\
\hline Great Shefford 22.5m & D & $5.25 \pm 0.09$ & $1.92 \pm 0.03$ & $3.29 \pm 0.05$ & $0.76 \pm 0.03$ & $0.99 \pm 0.06$ & $17.1 \pm 0.13$ & $0.26 \pm 0.01$ & 0.00 & 0.68 & $1.15 \pm 0.01$ & $2.74 \pm 0.17$ & $0.0 \pm 0.0$ & \\
\hline Great Shefford $22.5 \mathrm{~m}$ & D & $5.12 \pm 0.08$ & $1.80 \pm 0.03$ & $3.13 \pm 0.05$ & $0.72 \pm 0.02$ & $1.06 \pm 0.08$ & $19.0 \pm 0.12$ & $0.00 \pm 0.03$ & 0.00 & 4.32 & $1.15 \pm 0.01$ & $2.74 \pm 0.17$ & $0.0 \pm 0.1$ & \\
\hline Grumble Bottom 22m & $\mathrm{P}$ & $5.35 \pm 0.03$ & $2.25 \pm 0.01$ & $4.05 \pm 0.05$ & $0.98 \pm 0.03$ & $1.45 \pm 0.09$ & $8.37 \pm 0.08$ & $1.20 \pm 0.02$ & 0.00 & 1.64 & $1.44 \pm 0.01$ & $6.20 \pm 0.34$ & $2.0 \pm 0.3$ & $1.72 \pm 0.10$ \\
\hline Grumble Bottom 22m & D & $5.22 \pm 0.09$ & $2.24 \pm 0.04$ & $4.02 \pm 0.06$ & $0.93 \pm 0.04$ & $1.31 \pm 0.08$ & $9.31 \pm 0.15$ & $1.49 \pm 0.06$ & 0.15 & 0.34 & $1.46 \pm 0.02$ & $6.20 \pm 0.34$ & $2.0 \pm 0.5$ & \\
\hline Grumble Bottom 22m & D & $5.15 \pm 0.09$ & $2.19 \pm 0.03$ & $3.96 \pm 0.06$ & $0.97 \pm 0.03$ & $1.26 \pm 0.08$ & $9.40 \pm 0.20$ & $1.04 \pm 0.06$ & 0.04 & 2.62 & $1.46 \pm 0.01$ & $6.20 \pm 0.34$ & $2.2 \pm 0.5$ & \\
\hline Grumble Bottom 28m & $\mathrm{P}$ & $5.29 \pm 0.03$ & $2.26 \pm 0.01$ & $4.06 \pm 0.05$ & $0.93 \pm 0.02$ & $1.32 \pm 0.07$ & $9.05 \pm 0.10$ & $1.39 \pm 0.03$ & 0.04 & 0.93 & $1.45 \pm 0.01$ & $6.41 \pm 0.33$ & $1.8 \pm 0.2$ & $1.64 \pm 0.10$ \\
\hline Grumble Bottom 28m & D & $5.27 \pm 0.09$ & $2.25 \pm 0.04$ & $3.98 \pm 0.06$ & $0.94 \pm 0.04$ & $1.38 \pm 0.09$ & $9.46 \pm 0.14$ & $1.33 \pm 0.03$ & 0.00 & 0.41 & $1.44 \pm 0.02$ & $6.41 \pm 0.33$ & $1.6 \pm 0.7$ & \\
\hline Grumble Bottom 28m & D & $5.13 \pm 0.08$ & $2.27 \pm 0.03$ & $4.03 \pm 0.07$ & $0.93 \pm 0.03$ & $1.38 \pm 0.11$ & $9.26 \pm 0.17$ & $1.49 \pm 0.05$ & 0.05 & 0.13 & $1.43 \pm 0.01$ & $6.41 \pm 0.33$ & $1.5 \pm 0.1$ & \\
\hline Grumble Bottom 40m & $\mathrm{P}$ & $5.29 \pm 0.03$ & $2.28 \pm 0.01$ & $4.11 \pm 0.05$ & $0.91 \pm 0.03$ & $1.28 \pm 0.06$ & $12.4 \pm 0.04$ & $107 \pm 1.00$ & 0.84 & 0.31 & $1.46 \pm 0.01$ & $6.45 \pm 0.49$ & $2.1 \pm 0.3$ & $1.46 \pm 0.10$ \\
\hline Grumble Bottom 40m & D & $5.45 \pm 0.09$ & $2.31 \pm 0.04$ & $4.02 \pm 0.06$ & $0.97 \pm 0.04$ & $1.41 \pm 0.09$ & $9.13 \pm 0.11$ & $1.58 \pm 0.05$ & 0.00 & 0.95 & $1.46 \pm 0.02$ & $6.45 \pm 0.49$ & $2.2 \pm 0.6$ & \\
\hline Grumble Bottom $40 \mathrm{~m}$ & D & $5.26 \pm 0.09$ & $2.25 \pm 0.03$ & $4.09 \pm 0.07$ & $0.97 \pm 0.03$ & $1.37 \pm 0.11$ & $8.11 \pm 0.08$ & $1.16 \pm 0.02$ & 0.00 & 0.18 & $1.46 \pm 0.01$ & $6.45 \pm 0.49$ & $2.1 \pm 0.4$ & \\
\hline Oct-Nov 2012 & & & & & & & & & & & & & & \\
\hline Beche Park Wood 79m & $P$ & $5.49 \pm 0.07$ & $2.17 \pm 0.02$ & $4.21 \pm 0.07$ & $0.98 \pm 0.03$ & $1.42 \pm 0.07$ & $6.76 \pm 0.12$ & $0.91 \pm 0.04$ & 0.25 & 1.15 & $1.32 \pm 0.01$ & $3.26 \pm 0.21$ & $1.8 \pm 0.5$ & \\
\hline Beche Park Wood 79m & D & $5.38 \pm 0.10$ & $2.17 \pm 0.04$ & $4.01 \pm 0.08$ & $0.92 \pm 0.03$ & $1.23 \pm 0.10$ & $9.18 \pm 0.15$ & $1.25 \pm 0.04$ & 0.20 & 1.79 & $1.31 \pm 0.02$ & $3.26 \pm 0.21$ & $0.5 \pm 0.6$ & \\
\hline Beche Park Wood 79m & D & $5.55 \pm 0.09$ & $2.21 \pm 0.04$ & $4.01 \pm 0.08$ & $0.94 \pm 0.03$ & $1.46 \pm 0.11$ & $8.52 \pm 0.13$ & $1.07 \pm 0.03$ & 0.00 & 0.60 & $1.29 \pm 0.01$ & $3.26 \pm 0.21$ & $0.4 \pm 0.4$ & \\
\hline Beche Park Wood 89m & D & $4.72 \pm 0.08$ & $1.88 \pm 0.04$ & $3.44 \pm 0.07$ & $0.79 \pm 0.03$ & $1.13 \pm 0.09$ & $14.5 \pm 0.23$ & $0.00 \pm 0.02$ & 0.00 & 0.35 & $1.27 \pm 0.01$ & $3.38 \pm 0.21$ & $0.0 \pm 0.1$ & $2.19 \pm 0.10$ \\
\hline Beche Park Wood 89m & D & $5.61 \pm 0.10$ & $2.23 \pm 0.04$ & $4.04 \pm 0.08$ & $0.93 \pm 0.03$ & $1.30 \pm 0.11$ & $8.89 \pm 0.12$ & $1.47 \pm 0.04$ & 0.15 & 0.42 & $1.28 \pm 0.01$ & $3.38 \pm 0.21$ & $0.2 \pm 0.4$ & \\
\hline Brightwalton Common $78.5 \mathrm{~m}$ & D & $4.85 \pm 0.08$ & $2.10 \pm 0.04$ & $3.97 \pm 0.07$ & $0.91 \pm 0.03$ & $1.30 \pm 0.10$ & $8.84 \pm 0.17$ & $0.73 \pm 0.02$ & 0.17 & 0.61 & $1.34 \pm 0.01$ & $1.17 \pm 0.18$ & $0.0 \pm 0.1$ & \\
\hline Brightwalton Common $78.5 \mathrm{~m}$ & D & $5.12 \pm 0.08$ & $2.17 \pm 0.04$ & $3.93 \pm 0.08$ & $0.92 \pm 0.03$ & $1.41 \pm 0.11$ & $9.10 \pm 0.12$ & $1.02 \pm 0.03$ & 0.00 & 0.51 & $1.35 \pm 0.01$ & $1.17 \pm 0.18$ & $0.0 \pm 0.3$ & \\
\hline Brightwalton Common $88.5 \mathrm{~m}$ & D & $2.42 \pm 0.04$ & $1.03 \pm 0.02$ & $1.86 \pm 0.03$ & $0.43 \pm 0.01$ & $0.58 \pm 0.04$ & $60.7 \pm 1.22$ & $0.00 \pm 0.03$ & 0.00 & 474 & $1.37 \pm 0.01$ & $1.37 \pm 0.17$ & $0.2 \pm 0.1$ & $2.56 \pm 0.10$ \\
\hline Brightwalton Common $88.5 \mathrm{~m}$ & D & $1.76 \pm 0.03$ & $0.75 \pm 0.01$ & $1.33 \pm 0.03$ & $0.31 \pm 0.01$ & $0.47 \pm 0.04$ & $94.4 \pm 0.41$ & $0.00 \pm 0.01$ & 0.00 & 715 & $1.33 \pm 0.01$ & $1.37 \pm 0.17$ & $0.0 \pm 0.0$ & \\
\hline Cow Down $78.5 \mathrm{~m}$ & $\mathrm{P}$ & $6.30 \pm 0.08$ & $2.67 \pm 0.02$ & $4.78 \pm 0.08$ & $1.05 \pm 0.03$ & $1.56 \pm 0.07$ & $7.23 \pm 0.04$ & $45.2 \pm 0.55$ & 0.70 & 0.99 & $1.38 \pm 0.01$ & $0.63 \pm 0.13$ & $1.2 \pm 0.5$ & \\
\hline Cow Down $78.5 \mathrm{~m}$ & D & $5.56 \pm 0.09$ & $2.32 \pm 0.04$ & $3.93 \pm 0.07$ & $0.88 \pm 0.03$ & $1.19 \pm 0.09$ & $13.7 \pm 0.12$ & $40.3 \pm 1.01$ & 0.77 & 0.05 & $1.40 \pm 0.01$ & $0.63 \pm 0.13$ & $1.0 \pm 0.5$ & \\
\hline Cow Down $78.5 \mathrm{~m}$ & D & $5.63 \pm 0.09$ & $2.37 \pm 0.04$ & $3.88 \pm 0.07$ & $0.88 \pm 0.03$ & $1.33 \pm 0.10$ & $11.2 \pm 0.12$ & $2.27 \pm 0.07$ & 0.00 & 0.53 & $1.36 \pm 0.01$ & $0.63 \pm 0.13$ & $\mathrm{n} / \mathrm{a}$ & \\
\hline Cow Down $88.5 \mathrm{~m}$ & $\mathrm{P}$ & $\mathrm{n} / \mathrm{a}$ & $n / a$ & $n / a$ & $\mathrm{n} / \mathrm{a}$ & n/a & $\mathrm{n} / \mathrm{a}$ & $\mathrm{n} / \mathrm{a}$ & $n / a$ & $\mathrm{n} / \mathrm{a}$ & n/a & $0.84 \pm 0.14$ & $0.0 \pm 0.0$ & \\
\hline Cow Down $88.5 \mathrm{~m}$ & D & $6.20 \pm 0.11$ & $2.57 \pm 0.05$ & $4.36 \pm 0.09$ & $0.98 \pm 0.03$ & $1.34 \pm 0.10$ & $10.3 \pm 0.12$ & $32.7 \pm 1.05$ & 0.69 & 0.02 & $1.39 \pm 0.01$ & $0.84 \pm 0.14$ & $1.5 \pm 0.8$ & $2.12 \pm 1.00$ \\
\hline $\begin{array}{l}\text { Cow Down } 88.5 \mathrm{~m} \\
\text { May } 2011\end{array}$ & D & $6.19 \pm 0.11$ & $2.57 \pm 0.05$ & $4.33 \pm 0.09$ & $0.97 \pm 0.03$ & $1.38 \pm 0.11$ & $9.52 \pm 0.11$ & $21.3 \pm 0.54$ & 0.66 & 0.02 & $1.36 \pm 0.01$ & $0.84 \pm 0.14$ & $0.8 \pm 0.7$ & \\
\hline $\begin{array}{l}\text { May } 2011 \\
\text { Bagnor Cress Beds }\end{array}$ & $\mathrm{P}$ & $5.15 \pm 0.03$ & $2.08 \pm 0.03$ & $4.10 \pm 0.06$ & $0.91 \pm 0.02$ & $1.29 \pm 0.06$ & $8.53 \pm 0.09$ & $0.40 \pm 0.01$ & 0.25 & 7.32 & $1.40 \pm 0.01$ & $7.35 \pm 0.37$ & $2.6 \pm 0.3$ & $1.07 \pm 0.10$ \\
\hline Bagnor Cress Beds & D & $5.12 \pm 0.09$ & $2.12 \pm 0.03$ & $3.93 \pm 0.06$ & $0.90 \pm 0.03$ & $1.32 \pm 0.07$ & $9.73 \pm 0.15$ & $0.75 \pm 0.03$ & 0.12 & 0.36 & $1.39 \pm 0.02$ & $7.35 \pm 0.37$ & $1.6 \pm 0.6$ & \\
\hline Bagnor Cress Beds & D & $5.22 \pm 0.09$ & $2.14 \pm 0.03$ & $3.93 \pm 0.06$ & $0.92 \pm 0.03$ & $1.30 \pm 0.07$ & $9.65 \pm 0.22$ & $0.91 \pm 0.02$ & 0.16 & 0.16 & $1.43 \pm 0.01$ & $7.35 \pm 0.37$ & $2.6 \pm 0.6$ & \\
\hline East Garston & $\mathrm{P}$ & $4.98 \pm 0.03$ & $2.14 \pm 0.01$ & $4.02 \pm 0.05$ & $0.91 \pm 0.03$ & $1.26 \pm 0.06$ & $9.08 \pm 0.10$ & $0.90 \pm 0.03$ & 0.16 & 4.33 & $1.39 \pm 0.01$ & $5.36 \pm 0.28$ & $0.6 \pm 0.3$ & $1.31 \pm 0.10$ \\
\hline East Garston & D & $5.14 \pm 0.09$ & $2.16 \pm 0.03$ & $3.93 \pm 0.06$ & $0.91 \pm 0.03$ & $1.34 \pm 0.08$ & $9.66 \pm 0.15$ & $0.94 \pm 0.02$ & 0.04 & 0.17 & $1.37 \pm 0.02$ & $5.36 \pm 0.28$ & $0.6 \pm 0.5$ & 西 \\
\hline East Garston & D & $5.09 \pm 0.09$ & $2.17 \pm 0.04$ & $3.98 \pm 0.06$ & $0.91 \pm 0.03$ & $1.30 \pm 0.07$ & $9.43 \pm 0.13$ & $1.17 \pm 0.03$ & 0.19 & 0.69 & $1.35 \pm 0.01$ & $5.36 \pm 0.28$ & $0.0 \pm 0.2$ & \\
\hline Kimber & $\mathrm{P}$ & $6.27 \pm 0.04$ & $2.27 \pm 0.03$ & $4.20 \pm 0.06$ & $0.92 \pm 0.02$ & $1.34 \pm 0.06$ & $11.4 \pm 0.08$ & $102 \pm 1.40$ & 0.85 & 2.55 & $1.40 \pm 0.01$ & $4.49 \pm 0.26$ & $6.2 \pm 0.5$ & $1.24 \pm 0.10$ \\
\hline Kimber & D & $6.06 \pm 0.11$ & $2.29 \pm 0.03$ & $4.19 \pm 0.07$ & $0.95 \pm 0.03$ & $1.32 \pm 0.07$ & $11.7 \pm 0.05$ & $141 \pm 1.80$ & 0.85 & 0.06 & $1.36 \pm 0.01$ & $4.49 \pm 0.26$ & $3.8 \pm 0.8$ & \\
\hline Kimber & D & $6.08 \pm 0.11$ & $2.29 \pm 0.04$ & $4.08 \pm 0.07$ & $0.95 \pm 0.03$ & $1.31 \pm 0.08$ & $9.07 \pm 0.17$ & $1.79 \pm 0.06$ & 0.15 & 0.65 & $1.36 \pm 0.01$ & $4.49 \pm 0.26$ & $3.6 \pm 0.7$ & \\
\hline Oct 2011 & & & & & & & & & & & & & & \\
\hline Bagnor Cress Beds & $\mathrm{P}$ & $5.20 \pm 0.09$ & $2.11 \pm 0.02$ & $3.84 \pm 0.39$ & $0.79 \pm 0.39$ & $1.45 \pm 0.12$ & $8.01 \pm 0.12$ & $0.40 \pm 0.01$ & 0.00 & 0.61 & $1.49 \pm 0.03$ & $7.28 \pm 0.38$ & $4.5 \pm 0.9$ & $0.98 \pm 0.15$ \\
\hline Bagnor Cress Beds & D & $5.37 \pm 0.09$ & $2.18 \pm 0.04$ & $3.98 \pm 0.07$ & $0.93 \pm 0.02$ & $1.37 \pm 0.06$ & $9.23 \pm 0.15$ & $0.91 \pm 0.03$ & 0.00 & 0.11 & $1.44 \pm 0.03$ & $7.28 \pm 0.38$ & $3.2 \pm 0.8$ & \\
\hline Bagnor Cress Beds & D & $5.33 \pm 0.09$ & $2.16 \pm 0.04$ & $3.93 \pm 0.07$ & $0.93 \pm 0.02$ & $1.34 \pm 0.06$ & $9.54 \pm 0.25$ & $0.85 \pm 0.04$ & 0.00 & 0.07 & $1.39 \pm 0.03$ & $7.28 \pm 0.38$ & $2.1 \pm 0.8$ & \\
\hline Kimber & $\mathrm{p}$ & $6.10 \pm 0.11$ & $2.31 \pm 0.02$ & $3.95 \pm 0.39$ & $0.66 \pm 0.27$ & $1.55 \pm 0.13$ & $7.37 \pm 0.13$ & $1.40 \pm 0.03$ & 0.00 & 2.61 & $1.42 \pm 0.03$ & $4.00 \pm 0.23$ & $5.0 \pm 0.9$ & $0.59 \pm 0.15$ \\
\hline Kimber & D & $6.05 \pm 0.10$ & $2.28 \pm 0.04$ & $3.99 \pm 0.07$ & $0.92 \pm 0.02$ & $1.38 \pm 0.06$ & $9.63 \pm 0.11$ & $1.46 \pm 0.03$ & 0.00 & 0.74 & $1.38 \pm 0.02$ & $4.00 \pm 0.23$ & $4.1 \pm 0.7$ & \\
\hline Kimber & D & $6.13 \pm 0.10$ & $2.28 \pm 0.04$ & $4.01 \pm 0.07$ & $0.92 \pm 0.02$ & $1.37 \pm 0.06$ & $9.59 \pm 0.14$ & $1.47 \pm 0.04$ & 0.00 & 0.44 & $1.34 \pm 0.03$ & $4.00 \pm 0.23$ & $3.4 \pm 0.9$ & \\
\hline Woolstone Wells & $\mathrm{P}$ & $5.72 \pm 0.10$ & $2.13 \pm 0.02$ & $3.92 \pm 0.38$ & $0.72 \pm 0.30$ & $1.52 \pm 0.13$ & $6.93 \pm 0.06$ & $0.42 \pm 0.01$ & 0.00 & 1.36 & $1.16 \pm 0.03$ & $3.87 \pm 0.22$ & $0.0 \pm$ & $1.45 \pm 0.10$ \\
\hline Woolstone Wells & D & $5.68 \pm 0.10$ & $2.10 \pm 0.03$ & $3.91 \pm 0.07$ & $0.92 \pm 0.02$ & $1.42 \pm 0.06$ & $9.00 \pm 0.12$ & $0.49 \pm 0.01$ & 0.00 & 1.92 & $1.19 \pm 0.02$ & $3.87 \pm 0.22$ & $0.6 \pm 0.5$ & $1.45=0.10$ \\
\hline Woolstone Wells & D & $5.71 \pm 0.10$ & $2.10 \pm 0.03$ & $3.95 \pm 0.07$ & $0.91 \pm 0.02$ & $1.25 \pm 0.05$ & $9.75 \pm 0.12$ & $0.83 \pm 0.04$ & 0.22 & 2.68 & $1.18 \pm 0.02$ & $3.87 \pm 0.22$ & $0.1 \pm 0.3$ & \\
\hline Oct-Nov 2012 & & & & & & & & & & & & & & \\
\hline East Ginge & $\mathrm{P}$ & $5.60 \pm 0.10$ & $2.30 \pm 0.02$ & $4.14 \pm 0.06$ & $0.98 \pm 0.03$ & $1.30 \pm 0.07$ & $8.16 \pm 0.12$ & $1.86 \pm 0.05$ & 0.15 & 2.18 & $1.38 \pm 0.02$ & $4.75 \pm 0.27$ & $1.4 \pm 0.6$ & $1.48 \pm 0.10$ \\
\hline Letcombe Bassett & $\mathrm{P}$ & $5.36 \pm 0.06$ & $2.24 \pm 0.02$ & $4.08 \pm 0.05$ & $0.96 \pm 0.03$ & $1.33 \pm 0.07$ & $8.44 \pm 0.13$ & $1.32 \pm 0.03$ & 0.12 & 0.77 & $1.36 \pm 0.01$ & $2.46 \pm 0.24$ & $0.7 \pm 0.4$ & $1.58 \pm 0.10$ \\
\hline Woolstone Wells & $P$ & $5.46 \pm 0.07$ & $2.09 \pm 0.01$ & $4.04 \pm 0.07$ & $0.96 \pm 0.03$ & $1.37 \pm 0.06$ & $7.89 \pm 0.11$ & $0.33 \pm 0.01$ & 0.05 & 0.37 & $1.25 \pm 0.01$ & $4.56 \pm 0.25$ & $1.2 \pm 0.4$ & $1.53 \pm 0.10$ \\
\hline Jun 2013 & $\mathrm{P}$ & & & & & & & & & & & & & \\
\hline East Ginge & $\mathrm{P}$ & $5.64 \pm 0.07$ & $2.38 \pm 0.02$ & $4.46 \pm 0.07$ & $0.98 \pm 0.03$ & $1.45 \pm 0.07$ & $9.42 \pm 0.03$ & $95.2 \pm 0.70$ & 0.82 & 1.66 & $1.38 \pm 0.01$ & $6.57 \pm 0.29$ & $0.5 \pm 0.4$ & \\
\hline Letcombe Bassett & $\mathrm{P}$ & $5.20 \pm 0.07$ & $2.23 \pm 0.02$ & $3.92 \pm 0.06$ & $0.99 \pm 0.03$ & $1.40 \pm 0.07$ & $9.11 \pm 0.14$ & $1.20 \pm 0.03$ & 0.00 & 5.63 & $1.37 \pm 0.01$ & $2.44 \pm 0.16$ & $0.0 \pm 0.2$ & \\
\hline
\end{tabular}


Table S2. Noble gas data for groundwaters collected at the Boxford research site in August 2014. $F$ and $\chi^{2}$ are respectively the fractionation parameter and sum of the error-weighted deviations between modelled and measured noble gas concentrations for the CE method of EA and NGT calculation (Aeschbach-Hertig et al., 2008).

\begin{tabular}{|c|c|c|c|c|c|c|c|c|c|c|c|c|c|c|c|}
\hline \multirow[t]{2}{*}{ Piezo I } & \multicolumn{2}{|c|}{$\begin{array}{l}\text { Piezometer interval } \\
\text { m below } w / t\end{array}$} & \multirow[t]{2}{*}{ Type } & \multirow{2}{*}{$\begin{array}{r}\mathrm{He} \\
\times 10^{-8} \\
\end{array}$} & \multirow{2}{*}{$\begin{array}{l}\mathrm{Ne} \\
\times 10^{-7} \\
\end{array}$} & \multirow{2}{*}{$\begin{array}{c}\mathrm{Ar} \\
\mathrm{ccSTP} / \mathrm{g}- \\
\times 10^{-4} \\
\end{array}$} & \multirow{2}{*}{$\begin{array}{r}\mathrm{Kr} \\
\times 10^{-7} \\
\end{array}$} & \multirow{2}{*}{$\begin{array}{r}X e \\
\times 10^{-8} \\
\end{array}$} & \multirow[t]{2}{*}{$\begin{array}{l}\text { NGT } \\
{ }^{\circ} \mathrm{C}\end{array}$} & \multirow[t]{2}{*}{$\begin{array}{l}\text { Excess air } \\
\text { ccSTP/kg }\end{array}$} & \multirow[t]{2}{*}{$F$} & \multirow[t]{2}{*}{$\mathrm{x}^{2}$} & \multirow{2}{*}{$\begin{array}{r}{ }^{3} \mathrm{He} /{ }^{4} \mathrm{He} \\
\times 10^{-6} \\
\end{array}$} & \multirow[t]{2}{*}{$\begin{array}{l}{ }^{3} \mathrm{H} \\
\mathrm{TU}\end{array}$} & \multirow[t]{2}{*}{$\begin{array}{c}{ }^{3} \mathrm{H} \text { trit. } \\
\mathrm{TU}\end{array}$} \\
\hline & from & to & & & & & & & & & & & & & \\
\hline $\mathrm{A} 1$ & 22.05 & 22.55 & $P$ & $6.09 \pm 0.06$ & $2.27 \pm 0.03$ & $4.16 \pm 0.08$ & $9.34 \pm 0.02$ & $1.31 \pm 0.08$ & $11.9 \pm 0.06$ & $115 \pm 1.01$ & 0.85 & 0.33 & $1.27 \pm 0.02$ & $3.11 \pm 0.28$ & $2.0 \pm 0.6$ \\
\hline A2 & 0.00 & 0.70 & $P$ & $2.93 \pm 0.03$ & $1.24 \pm 0.01$ & $2.32 \pm 0.04$ & $5.13 \pm 0.01$ & $0.85 \pm 0.05$ & $46.5 \pm 0.66$ & $0.00 \pm 0.02$ & 0.00 & 630 & $1.34 \pm 0.02$ & $5.01 \pm 0.13$ & $0.0 \pm 0.0$ \\
\hline E1 & 23.65 & 24.35 & $\mathrm{P}$ & $\mathrm{n} / \mathrm{a}$ & $\mathrm{n} / \mathrm{a}$ & $n / a$ & $n / a$ & $n / a$ & $n / a$ & $\mathrm{n} / \mathrm{a}$ & $n / a$ & $\mathrm{n} / \mathrm{a}$ & $n / a$ & $3.28 \pm 0.04$ & $n / a$ \\
\hline E2 & 2.55 & 3.25 & $P$ & $5.39 \pm 0.05$ & $2.15 \pm 0.03$ & $4.12 \pm 0.08$ & $8.97 \pm 0.02$ & $1.37 \pm 0.09$ & $9.30 \pm 0.10$ & $0.94 \pm 0.01$ & 0.18 & 6.82 & $1.33 \pm 0.02$ & $4.34 \pm 0.06$ & $1.2 \pm 0.5$ \\
\hline G1 & 21.70 & 67.70 & $P$ & $6.52 \pm 0.05$ & $2.37 \pm 0.03$ & $4.13 \pm 0.07$ & $9.28 \pm 0.03$ & $1.32 \pm 0.09$ & $11.2 \pm 0.04$ & $30.0 \pm 0.64$ & 0.77 & 0.06 & $1.26 \pm 0.01$ & $4.48 \pm 0.15$ & $2.4 \pm 0.5$ \\
\hline G1 & 21.70 & 67.70 & $P$ & $6.33 \pm 0.07$ & $2.31 \pm 0.02$ & $4.16 \pm 0.07$ & $10.5 \pm 0.04$ & $1.42 \pm 0.15$ & $7.30 \pm 0.07$ & $1.39 \pm 0.03$ & 0.00 & 2.64 & $1.25 \pm 0.01$ & $4.48 \pm 0.15$ & $2.0 \pm 0.4$ \\
\hline G3 & 0.00 & 3.80 & $P$ & $5.06 \pm 0.04$ & $2.17 \pm 0.03$ & $4.16 \pm 0.09$ & $9.21 \pm 0.02$ & $1.35 \pm 0.09$ & $8.90 \pm 0.07$ & $1.01 \pm 0.03$ & 0.18 & 4.25 & $1.41 \pm 0.01$ & $6.24 \pm 0.08$ & $0.9 \pm 0.3$ \\
\hline G3 & 0.00 & 3.80 & $P$ & $5.09 \pm 0.06$ & $2.18 \pm 0.01$ & $4.07 \pm 0.07$ & $9.10 \pm 0.03$ & $1.28 \pm 0.13$ & $8.90 \pm 0.07$ & $0.97 \pm 0.04$ & 0.14 & 2.06 & $1.40 \pm 0.01$ & $6.24 \pm 0.08$ & $0.6 \pm 0.3$ \\
\hline $\mathrm{H} 1$ & 21.20 & 22.20 & $P$ & $6.11 \pm 0.05$ & $2.30 \pm 0.03$ & $4.30 \pm 0.07$ & $9.95 \pm 0.03$ & $1.48 \pm 0.10$ & $6.70 \pm 0.07$ & $1.48 \pm 0.05$ & 0.13 & 0.50 & $1.30 \pm 0.01$ & $3.64 \pm 0.24$ & $2.6 \pm 0.4$ \\
\hline $\mathrm{H} 2$ & 14.60 & 15.60 & $P$ & $5.77 \pm 0.04$ & $2.22 \pm 0.03$ & $4.12 \pm 0.07$ & $9.56 \pm 0.03$ & $1.37 \pm 0.09$ & $8.20 \pm 0.10$ & $1.19 \pm 0.03$ & 0.12 & 0.44 & $1.29 \pm 0.01$ & $4.23 \pm 0.05$ & $1.5 \pm 0.4$ \\
\hline 11 & 25.75 & 34.25 & $P$ & $6.37 \pm 0.04$ & $2.36 \pm 0.03$ & $4.34 \pm 0.08$ & $9.95 \pm 0.03$ & $1.58 \pm 0.11$ & $6.60 \pm 0.12$ & $1.85 \pm 0.05$ & 0.13 & 1.65 & $1.31 \pm 0.01$ & $3.14 \pm 0.04$ & $3.1 \pm 0.4$ \\
\hline 11 & 25.75 & 34.25 & $P$ & $6.32 \pm 0.07$ & $2.32 \pm 0.02$ & $3.99 \pm 0.07$ & $8.52 \pm 0.03$ & $1.19 \pm 0.13$ & $11.0 \pm 0.09$ & $2.08 \pm 0.03$ & 0.08 & 3.78 & $1.29 \pm 0.01$ & $3.14 \pm 0.04$ & $2.1 \pm 0.5$ \\
\hline 12 & 15.60 & 16.60 & $P$ & $6.03 \pm 0.05$ & $2.33 \pm 0.03$ & $4.22 \pm 0.09$ & $9.29 \pm 0.02$ & $1.30 \pm 0.09$ & $12.7 \pm 0.10$ & $113 \pm 1.91$ & 0.82 & 0.69 & $1.33 \pm 0.01$ & $3.77 \pm 0.16$ & $2.2 \pm 0.5$ \\
\hline 12 & 15.60 & 16.60 & $P$ & $6.14 \pm 0.07$ & $2.35 \pm 0.02$ & $4.14 \pm 0.07$ & $9.11 \pm 0.03$ & $1.25 \pm 0.13$ & $13.8 \pm 0.06$ & $120 \pm 0.93$ & 0.81 & 0.27 & $1.33 \pm 0.01$ & $3.77 \pm 0.16$ & $2.3 \pm 0.5$ \\
\hline
\end{tabular}


FIGURES 


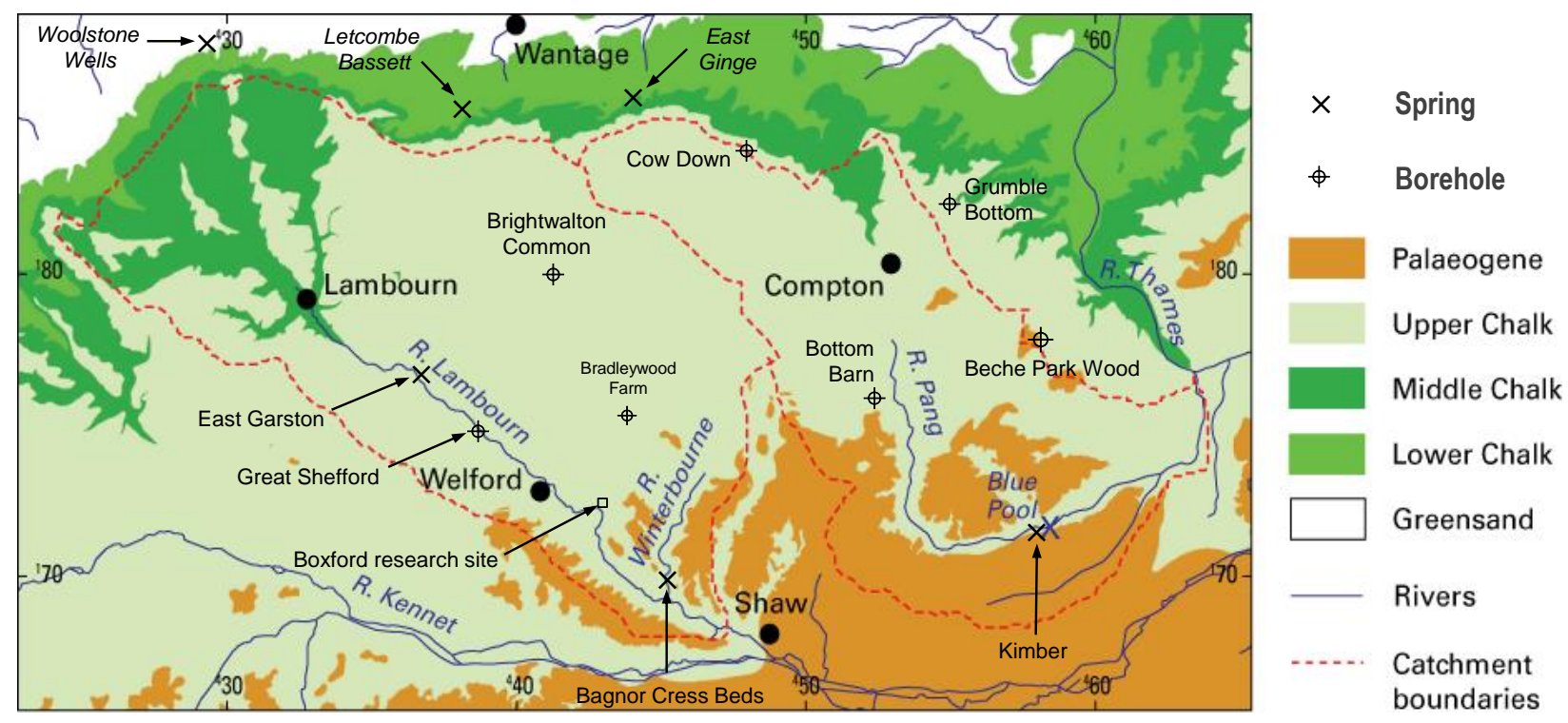

Fig. 1. Geological map of the Berkshire Downs showing locations of sampled springs, boreholes and the Boxford research site. $10 \mathrm{~km}$ grid tick marks shown. 

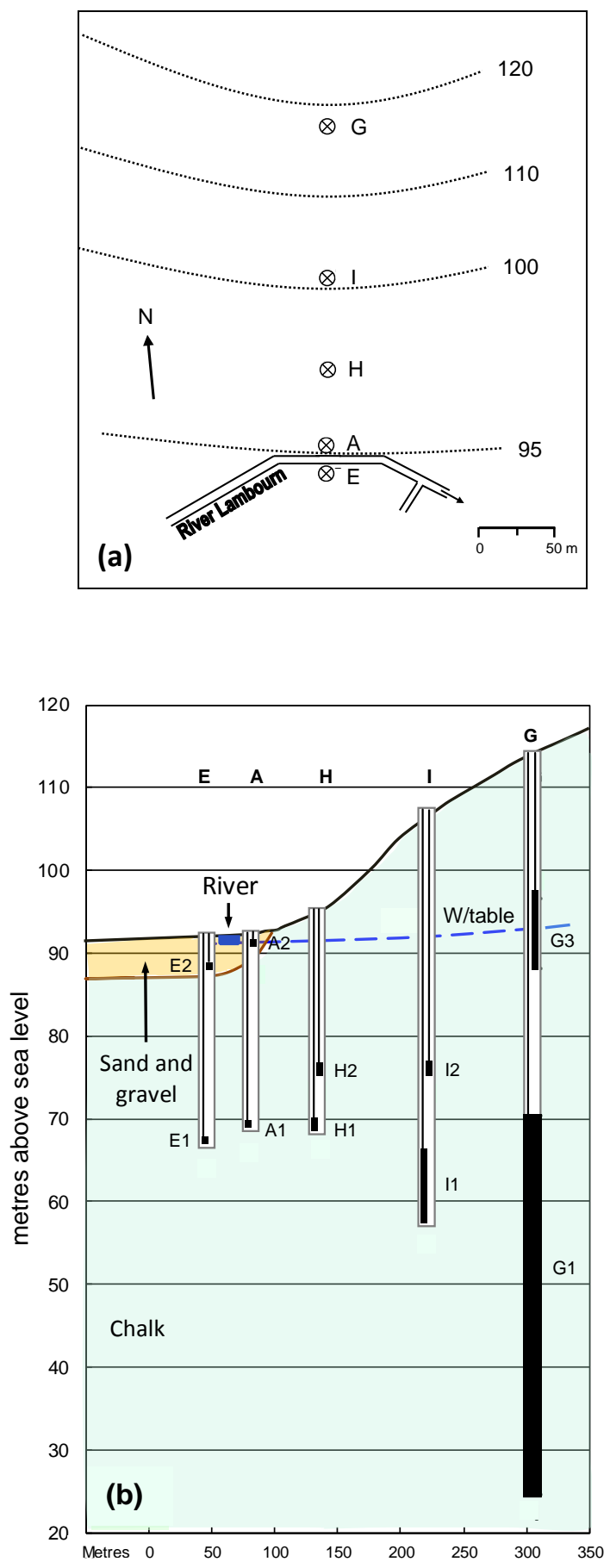

Fig. 2. The Boxford research site: (a) plan view of the piezometer array with ground surface elevation in metres, (b) a cross-section with simplified geology and the depth intervals of the five piezometer nests E A H I G, with numbers (E1, E2 etc). 


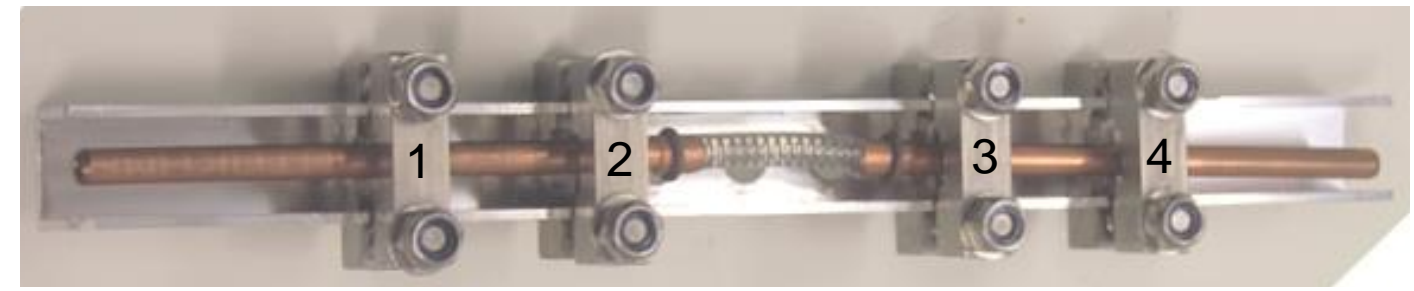

Fig. 3. Diffusion cell sampler, showing the central cell (silicone tubing, kept open underwater by the spiral wire support) and the two outer sample chambers ( $6 \mathrm{~mm}$ copper tubing) between the pinch clamps 1-4. Clamps 1 and 4 are closed before deployment, and clamps 2 and 3 as soon as possible after retrieval of the unit from the borehole or spring pool. 

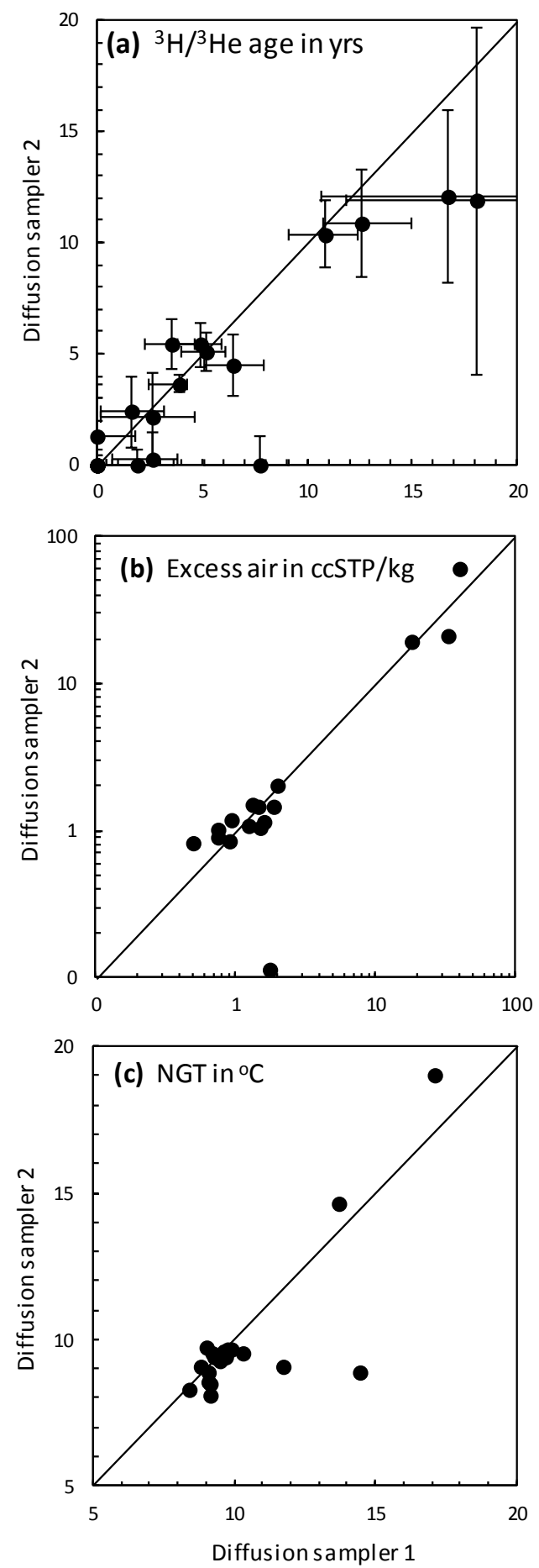

Fig. 4. Comparison of results from diffusion cell sampler pairs for $(a){ }^{3} \mathrm{H} /{ }^{3} \mathrm{He}$ age, (b) excess air and (c) noble gas temperature (NGT). Error bars are shown for ${ }^{3} \mathrm{H} /{ }^{3} \mathrm{He}$ age only since excess air and NGT error bars are within or close to the symbol size. 

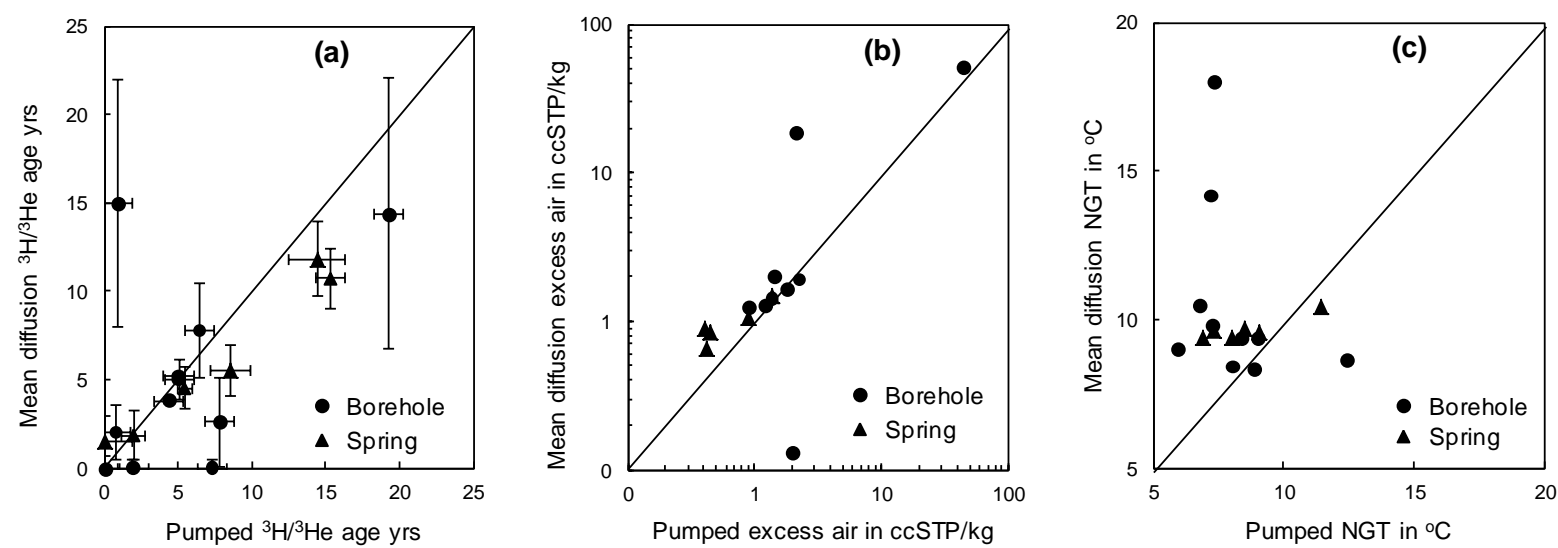

Fig. 5. Comparison of results from pumped tube and diffusion cell samples for (a) ${ }^{3} \mathrm{H} /{ }^{3} \mathrm{He}$ age, (b) excess air and (c) noble gas temperature (NGT). Error bars are shown for ${ }^{3} \mathrm{H} /{ }^{3} \mathrm{He}$ age only since excess air and NGT error bars are within or close to the symbol size. Where diffusion samples were collected in pairs, the average value has been used unless one measurement was clearly anomalous. 

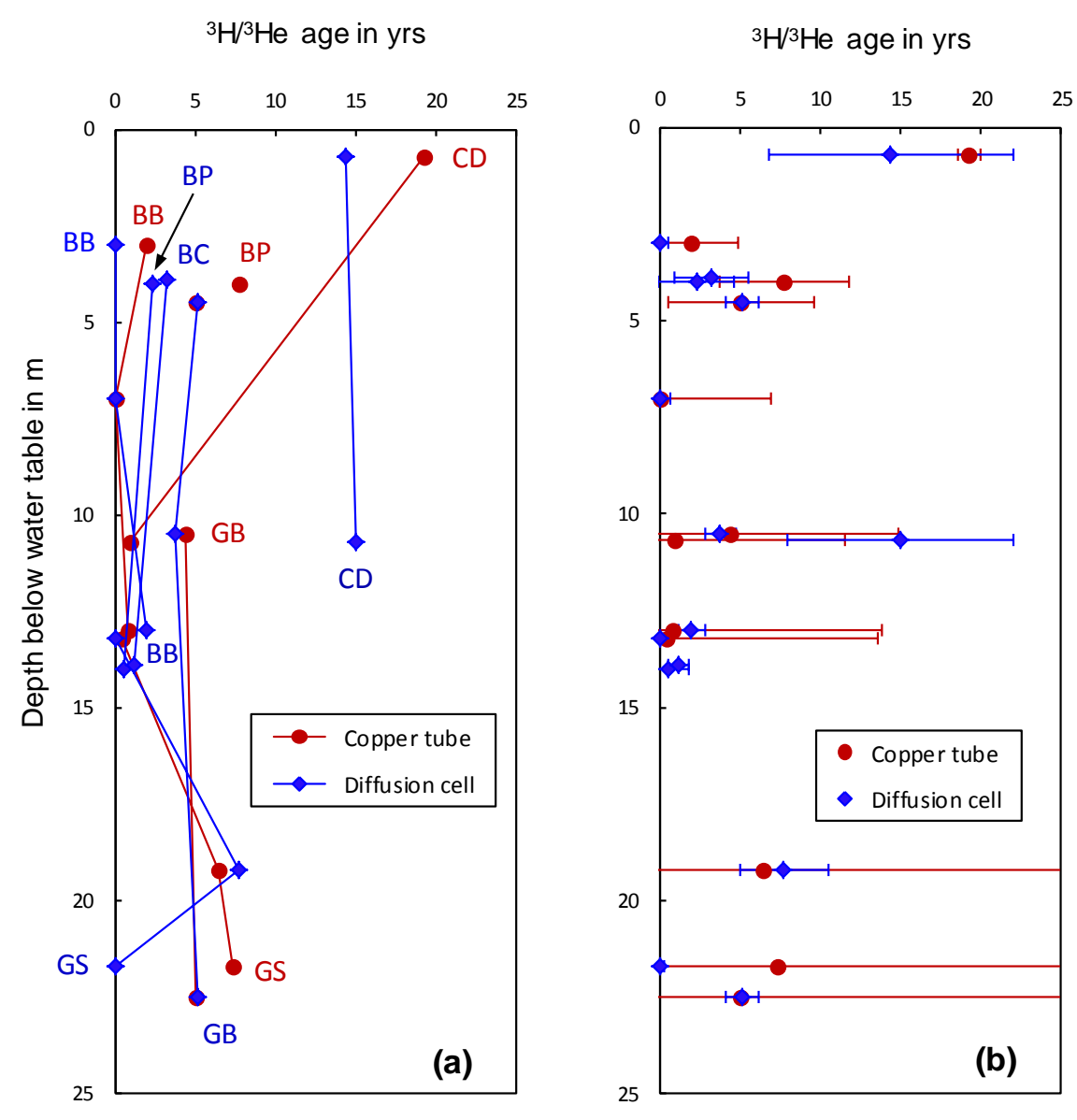

Fig. 6. Depth-age plots for selected Chalk boreholes on the Berkshire Downs comparing diffusion cell with pumped tube results, showing (a) profiles for the different boreholes, (b) the error bars on the ${ }^{3} \mathrm{H} /{ }^{3} \mathrm{He}$ ages. BB - Bottom Barn, BC - Brightwalton Common, BP - Beche Park Wood, CD - Cow Down, GB - Grumble Bottom, GS - Great Shefford. 

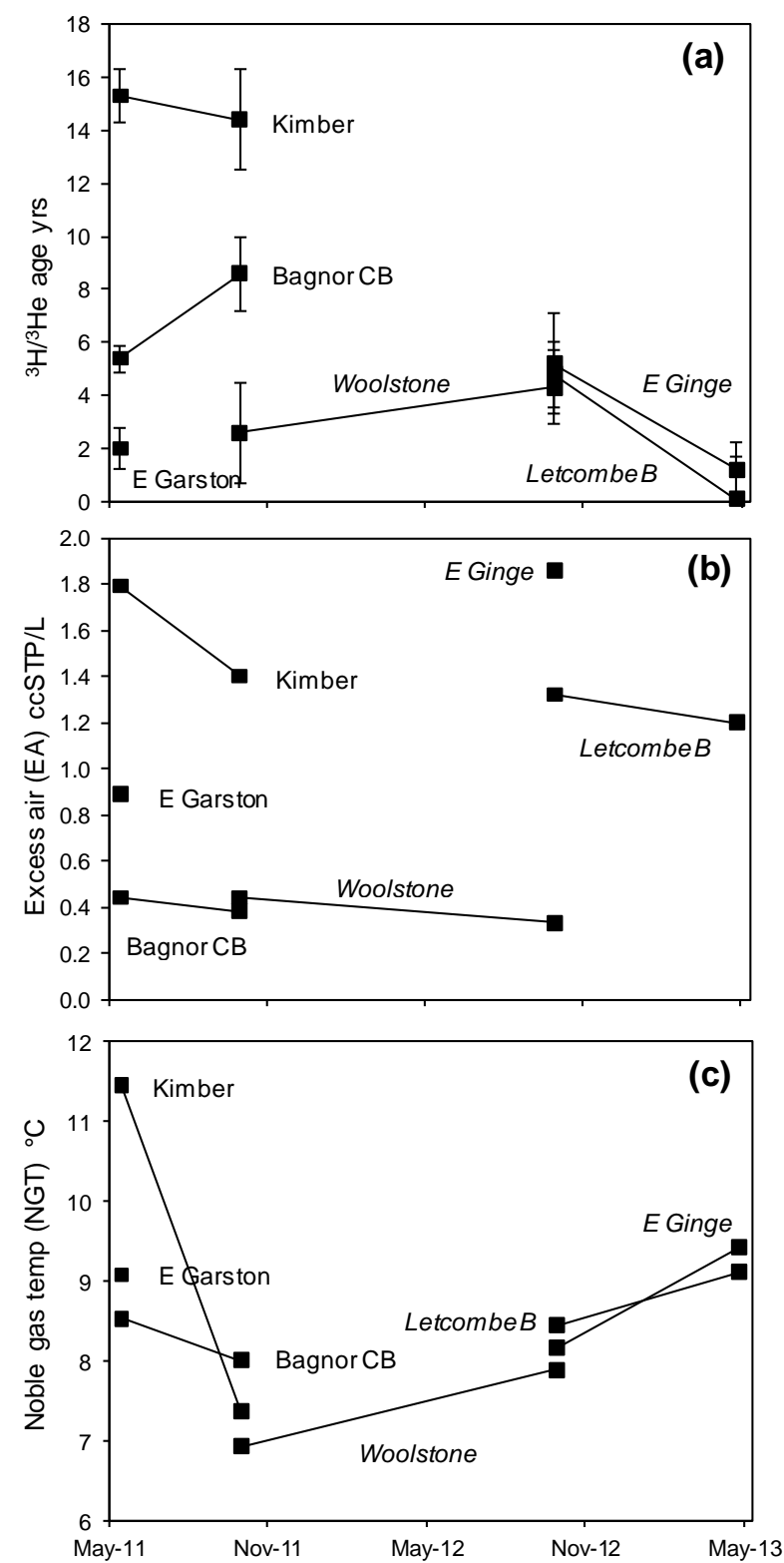

Fig. 7. Results from the seasonal sampling of noble gases in springs: (a) ${ }^{3} \mathrm{H} /{ }^{3} \mathrm{He}$ age, (b) excess air (EA), (c) noble gas temperature (NGT). Names of scarp slope springs are in italics. Error bars for EA and NGT are close to symbol size and are not shown. 


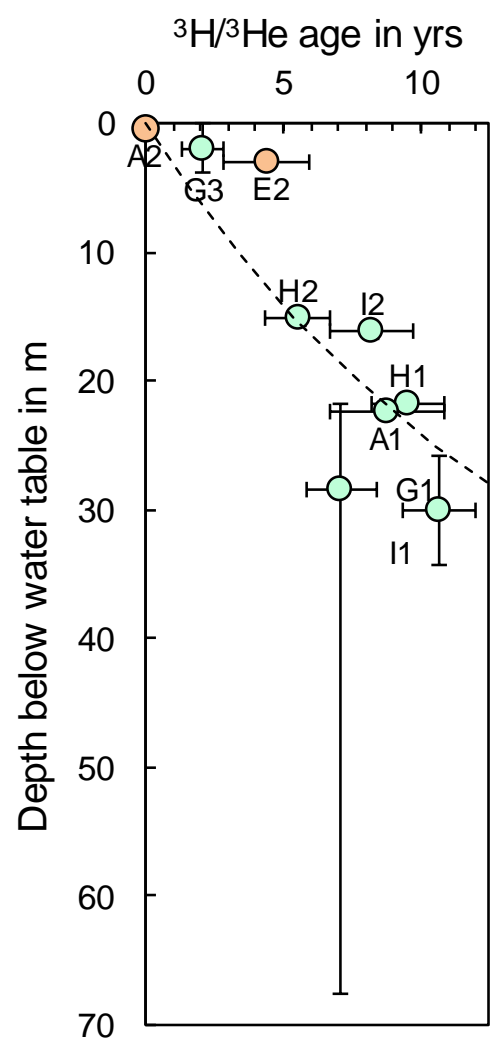

Fig. 8. ${ }^{3} \mathrm{H} /{ }^{3} \mathrm{He}$ ages for piezometers at the Boxford research site. Vertical error bars represent the screened interval, with the symbol at the depth of the pump intake. Infill colours reflect the geology shown in Fig. 7. The dashed line represents the Vogel (1967) model relating depth to age, in this case for a vertical flow velocity at the water table of $3.3 \mathrm{~m} / \mathrm{yr}$. 


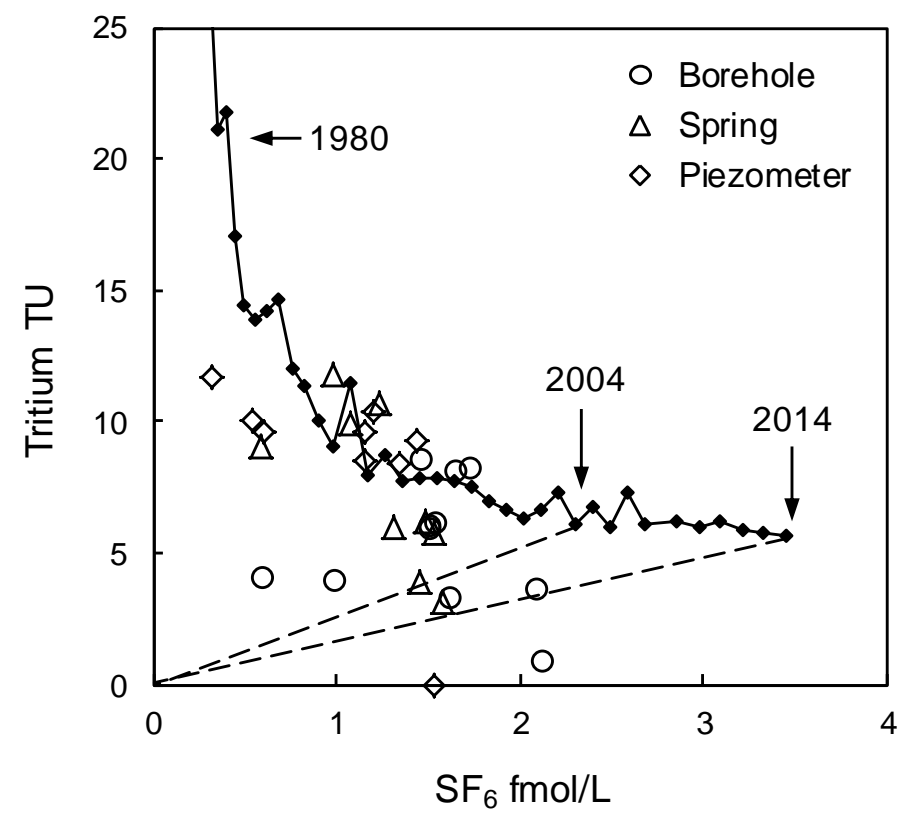

Fig. 9. Plot of tritium plus the tritiogenic ${ }^{3} \mathrm{He}$ equivalent against $\mathrm{SF}_{6}$ concentration for samples from boreholes, springs and Boxford piezometers. Also shown is the atmospheric input back to 1980 based on the mean of the Valentia and Groningen GNIP stations (https://nucleus.iaea.org/wiser) for tritium, and the USGS compilation for $\mathrm{SF}_{6}$ (http://water.usgs.gov/lab/software/air_curve/). The upper and lower dashed lines represent mixing between modern and pre-thermonuclear water in 2004 and 2014 respectively. 